\title{
Interference of silver nanoparticles with essential metal homeostasis in a novel enterghepaditicle Online \\ fish in vitro system
}

Matteo Minghetti ${ }^{1,4 \#}$ and Kristin Schirmer ${ }^{1,2,3^{*}}$

${ }^{1}$ Eawag, Swiss Federal Institute of Aquatic Science and Technology, Switzerland

${ }^{2}$ EPF Lausanne, School of Architecture, Civil and Environmental Engineering, Switzerland

${ }^{3}$ ETH Zürich, Institute of Biogeochemistry and Pollutant Dynamics, Switzerland

${ }^{4}$ Oklahoma State University, Department of Integrative Biology, USA

\# Corresponding author

Address: Department of Integrative Biology, 501 Life Sciences West, Oklahoma State University, Stillwater, OK 74078.

Email: matteo.minghetti@okstate.edu

*Address: Eawag, Swiss Federal Institute of Aquatic Science and Technology, Überlandstrasse 133, P.O. Box 611, 8600 Dübendorf, Switzerland

Email: kristin.schirmer@eawag.ch

This document is the accepted manuscript version of the following article:

Minghetti, M., \& Schirmer, K. (2019). Interference of silver nanoparticles with essential metal homeostasis in a novel enterohepatic fish in vitro system. Environmental Science: Nano.

https://doi.org/10.1039/C9EN00310J 
Abstract:

Silver nanoparticle toxicity has been extensively studied in several vertebrate cells. Its interaction with cellular essential metals homeostasis, however, has largely been overlooked. In this study, we used a novel in vitro model of the fish enterohepatic system to investigate the effect of citrate coated $\mathrm{AgNP}$ (cit-AgNP) and $\mathrm{AgNO}_{3}$ on the homeostasis of copper, iron and zinc. The intestine and the liver are key tissues for whole body absorption and processing of metals. The enterohepatic system is based on a co-culture of intestinal cells (rainbow trout gut, RTgutGC) grown on permeable supports and hepatic cells (rainbow trout liver, RTL-W1) grown in the sub-located well. We have investigated early responses to sub-toxic and toxic doses of cit- $\mathrm{AgNP}$ and $\mathrm{AgNO}_{3}$. Viability assays indicated that lysosomes were a target of cit-AgNP. Moreover, in comparison to $\mathrm{AgNO}_{3}$, cit-AgNPs elicit a similar but attenuated metal stress response (induction of MT mRNA and ATP7A protein trafficking). Metal quantification revealed that, while intestinal cells accumulated similar amounts of silver following non-toxic exposure to equivalent amounts of either $\mathrm{AgNO}_{3}$ or cit- $\mathrm{AgNP}$, cells exposed to $\mathrm{AgNO}_{3}$ excreted significantly more $\mathrm{Ag}$ to the basolateral chamber resulting in higher $\mathrm{Ag}$ accumulation in RTL-W1 cells. In addition, application of toxic doses of $\mathrm{AgNO}_{3}$ resulted in a reduction of intracellular zinc and iron. Silver nanoparticles were detected by STEM/EDX in RTgutGC after 3 hours of exposure but not after 24 hours suggesting rapid intracellular dissolution. Thus, Ag is a potent disruptor of essential metals homeostasis and cit-AgNP, which tend to be more difficult to excrete by the cell, can prolong this effect.

\section{Keywords: Metal homeostasis, in vitro, STEM/EDX, ATP7A trafficking, Metallothionein}




\section{Introduction}

Silver is much less toxic to humans than it is to bacteria. This difference in sensitivity is at the root of its widespread use in several consumer products. In addition, the antibacterial properties of silver in nanoparticle form is currently used in several products. These include medical applications, food supplements and food packaging, which implies the possibility of dietary uptake ${ }^{1}$. The use of AgNP have also been reported in aquaculture as a means to preventing diseases ${ }^{2,3}$. Uptake of AgNP can also occur via accidental exposure in polluted waters and fish were shown to accumulate significant amounts of silver in long-term AgNP mesocosm exposures ${ }^{4}$. However, uptake of silver and AgNP at the fish intestine is currently poorly understood due lack of an appropriate model to study interactions at the cell/medium interface ${ }^{5}$. The implications of silver exposure and the extent to which silver and AgNP are toxic to humans and the environment is still under debate ${ }^{6-8}$. For example, although it is evident that toxicity of AgNP relates to its capacity to release Ag ions which, in turn, results in oxidative stress ${ }^{9-13}$, its role in affecting the homeostasis of essential trace metals has only recently been considered. ${ }^{14,15}$ - Disruption of essential metal homeostasis might be an important mechanism of toxicity of such particles. 
Non-essential metals, such as silver, enter cells by hijacking systems evolved to uptake essentigalderticle Online metals ${ }^{16}$. Specifically, the uptake and intracellular metabolism of silver is inextricably linked to that of copper in virtually all species from bacteria to humans ${ }^{6}$. Molecular mechanisms shared by silver and copper include uptake via copper transporter $1(\mathrm{CTR} 1)^{17,18}$, excretion via Cu-ATPases ${ }^{19-21}$, and blood transport via the same plasma proteins ${ }^{22}$. Most importantly, silver can substitute copper in cupro-enzymes thereby inhibiting their activity (e.g. Ceruloplasmin ${ }^{23-25}$ and the $\mathrm{Cu} / \mathrm{Zn}-\mathrm{SOD}^{26,27}$ ). In mammals, silver has also been shown to disrupt the homeostasis of other essential trace elements such as zinc ${ }^{13}$, iron ${ }^{28}$ and selenium ${ }^{11}$. In fish, silver has been shown to be particularly toxic by interfering with chloride and sodium uptake ${ }^{29,30}$. The latter effect has also been shown specifically for AgNP in rainbow trout (Oncorhynchus mykiss) in vivo ${ }^{31}$ and in vitro ${ }^{32}$.

While uptake and homeostasis of essential and non-essential metals such as copper and silver are tightly regulated by copper transporters ${ }^{9,35,36}$, metal nanoparticles seem to bypass such mechanisms and enter the cell via endocytosis $5,32,35,36$. Therefore, AgNP uptake might be more difficult to control by the cell, resulting in the entry of a "big cargo" of zero-valent AgNP into cellular vesicles. Once inside the cell, AgNP seem to be directed to lysosomes whose internal milieu is characterized by an acidic $\mathrm{pH}$ that likely induces dissolution of silver from the NP surface ${ }^{5,32}$. It has been repeatedly shown that factors affecting ions dissolving from NPs, such as silver (Ag) ions in the case of AgNP or cobalt in the case of tungsten-carbide cobalt-NPs, are the cause of toxicity but cannot fully explain the observed biological effects ${ }^{6,37}$. Silver nanoparticle dissolution and speciation of the dissolved metal in the exposure media is an important determinant of toxicity for aquatic species where the NP is not taken up, or the internalization is minimal, such as algae ${ }^{38}$ and fish embryo ${ }^{39,40}$. However, the nature of the NPs interaction at the gill or intestinal epithelia of fish results in internalization via endocytosis, which minimizes the influence of extracellular AgNP chemical modifications and dissolved metal speciation. Indeed, modulation of chloride or cysteine concentrations in the exposure media, affected the toxicity of ionic silver $\left(\mathrm{AgNO}_{3}\right)$ but not the toxicity of AgNP in intestinal fish 
cells ${ }^{5}$. Therefore, the behavior of AgNP in the extracellular environment cannot fully predict bioavailability and ensuing toxicity.

Determination of the exposure scenarios that enhance or reduce NPs uptake, bioavailability, and toxicity is often difficult. This is due to the lack of appropriate biological models to study such phenomena. To allow investigations at the NP/cell interface we have used a model of the fish intestine derived from rainbow trout, the RTgutGC cell line $\mathrm{e}^{41,42}$. RTgutGC is a unique intestinal fish cell line, which, when grown on permeable supports (transwells), forms a cell monolayer dividing the system into an upper (apical) and a lower (basolateral) compartment, thereby mimicking the intestinal lumen and the portal blood, respectively (Figure 1 and $^{42,43}$ ). RTgutGC cells grown on transwells develop a polarized epithelium characterized by the expression of tight junction (ZO-1) and $\mathrm{Na} / \mathrm{K}$-ATPase proteins at the apical and basolateral membrane respectively ${ }^{42}$. Most importantly, RTgutGC cells tolerate exposures to well-defined synthetic simplified media that mimic different possible environmental scenarios (e.g. $\mathrm{pH}$, salinity, presence of proteins, etc.) occurring at the intestinal lumen, thus allowing the study of silver and AgNP interactions with the media components and, once internalized, with the intracellular environment (Figure $1 \mathrm{and}^{5,42}$ ).

This paper's focus is on the effect of silver in its ionic- $\left(\mathrm{AgNO}_{3}\right)$ and nano- (citrate-coated silver nanoparticles; cit-AgNP) form on the homeostasis of essential trace metals copper, zinc and iron using RTgutGC cells grown on permeable supports in combination with fish hepatic cells (rainbow trout liver, RTL-W144) grown in the sub-located well. This multi-cellular system represents a novel model of the fish enterohepatic system which allows the evaluation of the effect of silver compounds in the intestinal cells and on liver cells following intestinal processing. Moreover, we show the specific interference by silver on the homeostasis of copper, through the monitoring of the $\mathrm{Cu}$ ATPase protein trafficking in a mammalian intestinal model, the colorectal adenocarcinoma cells (Caco2). 


\section{Experimental}

\subsection{Nanoparticles characterization}

Citrate coated silver nanoparticles (cit-AgNPs) were purchased as aqueous suspension with a concentration of total silver of $1 \mathrm{~g} / \mathrm{L}(9.27 \mathrm{mM}, \mathrm{pH}$ 6.46, nominal size: $19 \mathrm{~nm}$, NanoSys GMbH, Switzerland). Extensive characterization of the same cit-AgNP in the same exposure solutions used

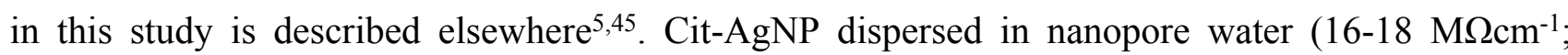
Barnstead Nanopure Skan AG, Switzerland) show a hydrodynamic diameter, measured by Dynamic Light Scattering, that is stable at $\sim 30 \mathrm{~nm}$ and the $\zeta$-potential is $-35 \mathrm{mV}$. In the exposure media L15/ex and L-15/FBS (see below), cit-AgNP form agglomerates of $\sim 540$ and $\sim 230 \mathrm{~nm}$ after 3 hours and of $\sim 1100$ and $\sim 250 \mathrm{~nm}$ in size after 24 hours and possess $\zeta$-potentials of -18 and $-9 \mathrm{mV}$, respectively ${ }^{5}$. In the exposure media DMEM, cit-AgNP form agglomerates of $\sim 355 \mathrm{~nm}$ after 3 hours and possess $\zeta$ - potentials of $-20 \mathrm{mV}$. A scanning transmission electron microscope (STEM, Hitachi HD-2700) was used to perform the Energy dispersive X-ray spectroscopy (EDX) analyses of citAgNP dispersed in nanopure water (Figure S1).

\subsection{Cell lines and culture media}

Routine cell culture: The RTgutGC cells were established by Kristin Schirmer, in the laboratory of Niels C. Bols (University of Waterloo). The RTL-W1 were provided by N.C. Bols. RTgutGC and RTL-W1 cells were routinely cultured as described in ${ }^{41}$ and ${ }^{44}$, respectively. Briefly, cells were grown in $75 \mathrm{~cm}^{2}$ flasks (TPP, Trasadigen, Switzerland) in Leibovitz's L-15 medium without phenol red (Invitrogen, Basel, Switzerland) supplemented with 5\% Foetal Bovine Serum (FBS, Gold, PAA Laboratories GmbH, Pasching, Austria) and $1 \%$ penicillin/streptomycin (Sigma-Aldrich, Buchs SG, Switzerland; $10000 \mathrm{U} / \mathrm{ml}$ penicillin, $10 \mathrm{mg} / \mathrm{ml}$ streptomycin). We will refer to this media as L15/FBS. Cells were maintained at $19^{\circ} \mathrm{C}$ in normal atmosphere and split into three flasks once confluent, which was every 2 to 3 weeks. Confluent flasks were washed twice with Versene 


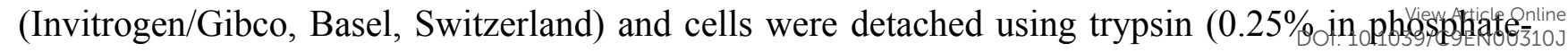
buffer saline, PBS, Biowest, Nuaille, France). Human intestinal cells, Caco-2, were purchased from ATCC (ATCC® HTB-37'M $)$ and grown in D-MEM medium with phenol red (Gibco/Invitrogen, Basel, Switzerland) supplemented with 10\% FBS and 1\% penicillin/streptomycin. Cells were maintained at $37^{\circ} \mathrm{C}$ and $5 \% \mathrm{CO}_{2}$. Sub-culturing was performed as for RTgutGC and RTL-W1 but every 3 days.

Cell culture on permeable membranes: RTgutGC and Caco-2 cells were seeded onto commercially available transparent tissue culture inserts for multiwell plates (pore size $=0.4 \mu \mathrm{m}$; polyethylene terephthalate [PET] from Greiner bio-one, Frickenhausen, Germany). Insert size was chosen depending on the application: inserts for $24-w e l l$ plates $\left(0.33 \mathrm{~cm}^{2}\right.$ surface area) were used for cell viability, confocal microscopy and electron microscopy; inserts for 12 -well plates $\left(1.13 \mathrm{~cm}^{2}\right.$ surface area) for quantitative RT-PCR (qPCR) analyses; and inserts for 6-well plates $\left(4.25 \mathrm{~cm}^{2}\right.$ surface area) for silver and cit-AgNP quantification. Previous to cell seeding, to enhance cell attachment, inserts were incubated at room temperature for $3 \mathrm{hrs}(\mathrm{hrs})$ with fibronectin $(50 \mu \mathrm{g} / \mathrm{mL}$; Roche Applied Science, Basel, Switzerland) in PBS (Bioswisstec AG, Schaffhausen, Switzerland), then washed once with $\mathrm{PBS}^{42}$. To initiate cultures on inserts, RTgutGC and Caco- 2 cells, dislodged by trypsin, were re-suspended in respective growth medium and added at a density of $62500 \mathrm{cell} / \mathrm{cm}^{2}$. The insert well (or top compartment) is referred to as the "apical chamber" whereas the sub-located well (or bottom compartment) as "basolateral chamber" (Figure 1). Apical chamber was filled with 0.3, 1 and $3.5 \mathrm{~mL}$ of growth medium (L-15/FBS), for 24-, 12- and 6-well inserts, respectively. These were then placed in the corresponding culture wells (referred to as basolateral compartment), which were subsequently filled with, respectively, 1, 1.7 and $4 \mathrm{~mL}$ of L-15/FBS. The media was changed weekly for RTgutGC and every $48 \mathrm{hrs}$ for Caco-2 cells. It was determined that confluent and polarized epithelia would form in 3 weeks for $\mathrm{RTgutGC}^{42}$ and 2 weeks for Caco- 2 cells ${ }^{46}$, after which the epithelia are defined as developed. 


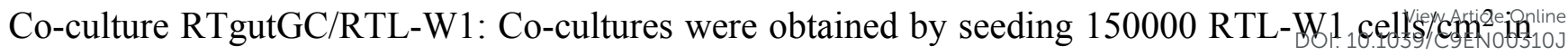
the bottom of the basolateral chamber (e.g. 12-well plates; Greiner Bio-ONE, Frickenhausen, Germany). Previous to exposure, RTL-W1 were incubated for $48 \mathrm{hrs}$ in L-15/FBS. Then monolayers were washed twice with PBS and the exposure medium L-15/ex was applied ${ }^{47}$. Subsequently, developed RTgutGC epithelia grown on inserts were washed likewise and mounted on top (Figure $1)$.

TEER Measurement: The development of a confluent intestinal epithelium was monitored daily through 'blank'-corrected measurements of transepithelial electrical resistance (TEER) using an epithelial tissue voltohmeter (EVOMX; World Precision Instruments) fitted with chopstick electrodes (STX-2). As blank controls, empty (no cell) inserts, treated identically to the inserts containing cells, were used. A TEER of $\sim 30$ or $\sim 250 \Omega \times \mathrm{cm}^{2}$ was used as a criterion for the presence of a sufficiently tight epithelium for $\mathrm{RTgutGC}^{42,43}$ or Caco2 cells $\mathrm{s}^{46}$, respectively.

\subsection{Exposures of cells to silver}

Experimental solutions were prepared freshly in the respective cell exposure media. Silver nitrate (Sigma-Aldrich, Buchs SG, Switzerland) stock solution was prepared at a concentration of $10 \mathrm{mM}$ in nanopure water and diluted right before each experiment in the appropriate cell exposure medium. Silver nitrate $\left(\mathrm{AgNO}_{3}\right)$ and cit-AgNP stock solutions were prepared to contain identical nominal concentrations of total silver. Exposure media were L-15/FBS or L-15/ex. L-15/ex has an identical composition in salts, glucose and pyruvate to L-15 but lacks amino acids and vitamins ${ }^{47}$. To initiate exposure, the developed RTgutGC cell epithelium was first washed twice with either L-15/FBS or L15/ex depending on the planned exposure conditions. Subsequently, for the viability assay $0.3 \mathrm{~mL}$ per transwell of cit-AgNP or $\mathrm{AgNO}_{3}$ suspensions were applied at concentrations ranging from 0.1 to $500 \mathrm{mM}$ in the respective media. RTL-W1 were exposed only indirectly i.e. in the basolateral chamber (see Figure 1). For the qPCR and metal analysis 1 and $3.5 \mathrm{~mL}$ of cit-AgNP or $\mathrm{AgNO}_{3}$ suspensions were added to the 12 and 6 well transwell in the respective media. Cells were exposed to 


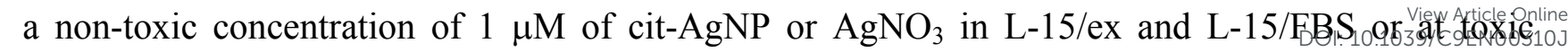
(EC20) concentrations of $3.4 \mu \mathrm{M} \mathrm{AgNO}$ and $10 \mu \mathrm{M}$ cit-AgNP in L-15/ex as determined by the viability assay (see below). The exposure of cell analyzed by electron or confocal microscopy in indicated below. Cells were incubated in the dark at $19^{\circ} \mathrm{C}$ for 3 or $24 \mathrm{hrs}$ depending on the assay to be performed (see below).

\subsection{Cell viability assays}

Assessment of cell viability was accomplished by means of the fluorescent cell viability indicator dyes, alamar Blue (AB, Invitrogen, Basel, Switzerland), CFDA-AM (Invitrogen, Basel, Switzerland) and Neutral Red (NR, Sigma-Aldrich, Buchs SG, Switzerland), as previously described ${ }^{47}$. Responses of $\mathrm{AB}$ and CFDA-AM were comparable and therefore only $\mathrm{AB}$ data are shown. Alamar blue is a cellular marker of cellular metabolic activity and Neutral Red of lysosome membrane integrity ${ }^{48}$. Cell viability was assessed on RTgutGC cells cultured in inserts for 24 well plates $\left(0.33 \mathrm{~cm}^{2}\right)$ and RTL-W1 seeded in the bottom of the basolateral chamber. At the time of assessment (3 or $24 \mathrm{hrs),}$ the exposure medium was aspirated from both the apical and basolateral compartment and cells washed once with PBS. Then, 100 and $400 \mu \mathrm{L}$ of $\mathrm{AB}$, at $5 \%(\mathrm{v} / \mathrm{v})$ in PBS, was applied to the apical and basolateral chamber, respectively. Cells were incubated in the dark at $19^{\circ} \mathrm{C}$ for 30 min and then fluorescence recorded with a Tecan Infinite M200 multiwell plate reader (Maennedorf, Switzerland) at an excitation/emission wavelength of 530/595. To account for the small area of the insert and the fact that the position of inserts may shift slightly in the wells, readings were adjusted so as to measure 21 points, of which an estimated nine central measurements covered the insert surface area. These were averaged for analysis assuming that they best reflect the fluorescence in the centre of the inserts, which was supported by a very small variation among these nine values ${ }^{42}$. Afterward, the AB working solution was discarded and $400 \mu \mathrm{L}$ of NR solution, containing $1.5 \% \mathrm{v} / \mathrm{v} \mathrm{NR}$ in PBS, was added and incubated for $120 \mathrm{~min}$. Then, cells were fixed with $400 \mu \mathrm{L}$ fixative $(0.5 \% \mathrm{v} / \mathrm{v}$ 
formaldehyde and $1 \% \mathrm{w} / \mathrm{v} \mathrm{CaCl}_{2}$ ). Finally, $\mathrm{NR}$ was extracted from the lysosomes using 440.90 Vign Artife extraction solution $(1 \% \mathrm{v} / \mathrm{v}$ acetic acid and $50 \% \mathrm{v} / \mathrm{v}$ ethanol) and gently shaken on a horizontal shaker (TiMix 2, Johanna Otto $\mathrm{GmbH}$, Hechingen, Germany) for $10 \mathrm{~min}$. NR fluorescence was measured at excitation/emission wavelengths of 530/645nm using the same plate reader.

\subsection{Metal analyses}

Metal quantification was assessed on RTgutGC cells cultured on inserts $\left(4.25 \mathrm{~cm}^{2}\right)$ and in RTL-W1 cells cultured underneath in 6 well plates. After exposure, the basolateral and apical media were aspirated carefully, taking care to avoid carry-over from possible cit-AgNP sedimented on the cell monolayer, and transferred to an Eppendorf tube for silver quantification. Next, to ensure thorough removal of loosely bound silver, cells were washed twice with a solution of $0.5 \mathrm{mM}$ Cysteine in PBS. Cells were then lysed by applying $0.5 \mathrm{~mL}$ of $50 \mathrm{mM} \mathrm{NaOH}$ to the well and incubated at room temperature for $2 \mathrm{hrs}^{49}$. An aliquot $(100 \mu \mathrm{L})$ of the cells' lysate was used for protein quantification using the modified Lowry assay (Thermo Scientific, Waltham, USA) with bovine serum albumin as standard. For metal determination, media and cell lysates were desiccated using a concentrator (Concentrator Plus, eppendorf, Hamburg, Germany) and digested over-night by adding $0.8 \mathrm{~mL}$ of $65 \% \mathrm{HNO}_{3}$. Acidified solutions were then re-suspended and transferred to a Teflon tube containing $0.2 \mathrm{~mL}$ of $30 \% \mathrm{H}_{2} \mathrm{O}_{2}$ and digested further in a high-performance microwave digestion unit (MLS1200 MEGA, Switzerland) at a maximum temperature of $195^{\circ} \mathrm{C}$ for $20 \mathrm{~min}$. The digest was then diluted 10 times with nanopure water and measured. Metal concentration was measured in media and cells by ICP-MS (Element 2 High Resolution Sector Field ICP-MS, Thermo, Finnigan, Germany). The reliability of the measurement was determined using specific water references (M105A, IFA System, Tull, Austria). Metal concentration in cell lysates is reported as ng metal per mg of protein to take into account cell growth. Silver accumulation and transport across the intestinal epithelium is reported as absolute amount (i.e. ng Ag in the medium of the apical or basolateral compartment, and in the cell monolayer). 
Messenger RNA quantification was assessed in RTgutGC cells cultured on inserts $\left(1.13 \mathrm{~cm}^{2}\right)$ and in RTL-W1 cells cultured underneath in 12 well plates. RNA extraction, DNAse treatment, cDNA synthesis and measurement of mRNA levels were performed as described previously ${ }^{50}$. Briefly, after exposure, total RNA was extracted by adding $600 \mu \mathrm{L}$ of TRIzol ${ }^{\circledR}$ Reagent (Invitrogen, Basel, Switzerland) directly onto the RTgutGC cell monolayer grown in inserts or onto the RTL-W1 cells. The quantity and quality of isolated RNA was determined by spectrophotometry with an ND-1000 Nanodrop (Labtech Int., East Sussex, UK) and by electrophoresis using $0.5 \mu \mathrm{g}$ of total RNA in a $1 \%$ agarose gel. At each time point, total RNA was extracted from an untreated and a treated sample. Messenger RNA levels are reported as fold change of the treated from the untreated sample. Normalization was based on the geometric mean expression of two reference genes ( $\beta$-actin and elongation factor $1 \alpha$ ) determined using geNorm software ${ }^{51}$. Primer sequences are reported in Table S1.

\subsection{Electron microscopy and Energy-dispersive X-ray spectroscopy}

In order to prepare samples for electron microscopy, RTgutGC cells were cultured on inserts as indicated above. Developed RTgutGC epithelia were exposed to $50 \mu \mathrm{M}$ cit-AgNP dispersed in L15/ex for $3 \mathrm{hrs}$ and to $10 \mu \mathrm{M}$ cit-AgNP dispersed in L-15/ex and L-15/FBS for $24 \mathrm{hrs}$. All these exposures were not cytotoxic (data not shown). Previous to fixing, cell monolayers were washed as described in the metal analysis section. The PET membrane containing the cells was carefully excised from the insert. The samples were fixed in phosphate-buffered $2.5 \%$ glutaraldehyde, postfixed in $1 \%$ osmium tetroxide and block stained with $1 \%$ uranyl acetate, then dehydrated in a graded ethanol series and finally embedded in Epon-resin (EMbed 812, EMS). After polymerization at $60^{\circ} \mathrm{C}$, ultrathin sections of about $100 \mathrm{~nm}$ thickness were cut on an ultra-microtome (Reichert Ultracut C) perpendicular to the cell monolayer. Due to different material properties of resin and 


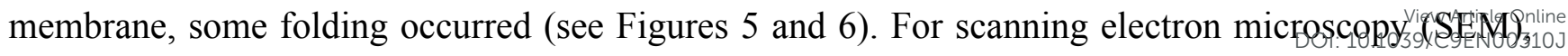
the ultrathin sections were transferred onto silicon chips. No post-staining was applied. Micrographs were taken on a FEI Magellan 400 at $2 \mathrm{kV}$ by backscatter electron detection. Large area scans were performed by stitching individual image tiles (FEI Maps software). A scanning transmission electron microscope (STEM, FEI Tecnai F30ST) was used to acquire electron micrographs and the energy dispersive X-ray (EDX) spectroscopy measurements.

\subsection{ATP7A trafficking}

Evaluation of the copper efflux pump (ATP7A) function, via monitoring of its trafficking behaviour, was evaluated via imaging and co-localization of ATP7A with actin, or with the Trans Golgi Network (TGN). The human ATP7A antibody was kindly gifted by Dr Adam Southon (Melbourne University). The TGN marker, the antibody Golgin97 and the actin stain, rhodamine phalloidin, were purchased from Invitrogen, Basel, Switzerland. This assay was only possible in Caco2 cells because of antibody specificity. The trafficking assay in $\mathrm{CaCo} 2$ cells was performed as previously described $^{52}$ including appropriate controls such as excess $\mathrm{Cu}\left(100 \mu \mathrm{M} \mathrm{CuSO}_{4}\right)$ and $\mathrm{Cu}$ starvation via pre-exposure with the $\mathrm{Cu}$ chelator, bathcuproine disulphate (BCS). Developed Caco2 epithelia were exposed for $18 \mathrm{hrs}$ in low serum media (DMEM, Invitrogen, Basel, Switzerland, supplemented with $5 \%$ FBS) containing $200 \mu \mathrm{M}$ of BCS prior to treatment with $200 \mu \mathrm{M} \mathrm{BCS,} 100 \mu \mathrm{M} \mathrm{CuSO}_{4}, 10 \mu \mathrm{M}$ $\mathrm{AgNO}_{3}$ or $80 \mu \mathrm{M}$ cit-AgNP dissolved or dispersed in DMEM for 3 hrs. Toxicity in CaCo2 cells was evaluated as described for RTgutGC. All doses of exposure were not cytotoxic (data not shown). Following exposures, cells were prepared for confocal microscopy. Two inserts were washed twice with PBS and fixed by incubation in a solution of $3.7 \%$ paraformaldehyde (Sigma-Aldrich, Buchs SG, Switzerland) in PBS for $15 \mathrm{~min}$ at room temperature. Permeabilization was achieved by incubating the cells in a solution of $0.2 \%(\mathrm{v} / \mathrm{v})$ Triton (Sigma-Aldrich, Buchs SG, Switzerland) in PBS for 30 minutes (min) at $4^{\circ} \mathrm{C}$. The "image-it" solution (Molecular Probes, Invitrogen, Basel, Switzerland) was used for blocking nonspecific signals following manufacturer instructions. Primary 
antibodies were diluted (ATP7A 1:400; Golgin97 1:200) in 1\% goat sera and $0.05 \%$ Tritions Alexa Fluor ${ }^{\circledR}$ 488-anti-rabbit antibody and Alexa Fluor ${ }^{\circledR}$ 635-anti-mouse antibody were used at a 1:200 dilution as secondary antibodies for ATP7A and Golgin97, respectively. Primary antibody incubation was performed overnight at $4^{\circ} \mathrm{C}$, while incubation with secondary antibody and the f-actin staining (Rhodamine-phalloidin, Invitrogen, Basel, Switzerland), applied at 2 Unit/mL in PBS, was done for one hour at room temperature. Nuclear counter staining was achieved by incubating cells with $300 \mathrm{nM}$ DAPI (Invitrogen, Basel, Switzerland) for $5 \mathrm{~min}$ at room temperature. Finally, the PET membrane holding the cells was excised and mounted on a microscope slide (Thermo Scientific, Zug, Switzerland) covered with ProLong Antifading solution (Invitrogen, Basel, Switzerland). Imaging was performed using a Leica SP5 (Wetzlar, Germany) upright confocal laser-scanning microscope, equipped with the acquisition software LAS AF 2.6.v. The 63X OIL (NA 1.4) objective was used. Images at each wavelength (405 nm for DAPI, $488 \mathrm{~nm}$ for Alexa488 conjugated secondary antibody, $543 \mathrm{~nm}$ for Rhodamine-phalloidin and $633 \mathrm{~nm}$ for the Alexa635 conjugated secondary antibody) were acquired sequentially. Signals from five Fields Of View (FOVs; $5337 \pm 350 \mu \mathrm{m}^{2}$ ) were analyzed by the co-localization module of the LAS AF 2.6v software. The ATP7A trafficking experiment was performed three times.

\subsection{Statistical analyses}

Statistical analysis was performed using GraphPad Prism Version 5 (GraphPad Software, USA). Fluorescent units obtained in the cell viability assays were converted to percentage viability of control cells. Concentrations leading to 50\% reduction in viability (EC50) were determined by the nonlinear regression sigmoidal dose-response curve fitting module using the Hill slope equation. EC values are presented as mean and $95 \%$ confidence intervals. Difference between curves was assessed by F-test $(\mathrm{p}<0.05)$. Statistical analysis for multiple groups of data was performed by analysis of variance (ANOVA) followed by Tukey's post hoc test. When comparing to a control group, 


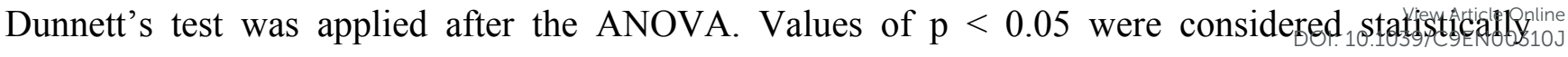
significant.
\end{abstract}

\title{
3. Results and Discussion
}

\subsection{Citrate coated AgNP characterization in exposure medium}

Characterization of the cit-AgNP (NanoSys GMbH, Switzerland) dispersed in the exposure media L15/ex and L-15/FBS has been previously reported ${ }^{5,45}$. Briefly, cit-AgNP agglomerate rapidly in L15/ex reaching $1064 \mathrm{~nm}$ in size and a $\xi$-potential of about $-18 \mathrm{mV}$ in $24 \mathrm{hrs}$. On the other hand, in L15/FBS, cit-AgNP agglomerate moderately to about $250 \mathrm{~nm}$ and show a $\xi$-potential of $-9 \mathrm{mV}$. In DMEM without FBS after 3 hours, cit-AgNP agglomerate to about $360 \mathrm{~nm}$ and $\xi$-potential of -20 $\mathrm{mV}$ which is similar to their size and charge in L-15/ex. This data suggests that in the absence of FBS, the nanoparticle agglomeration can be mainly explained by the media ionic strength ${ }^{37,53}$. In addition, elemental analysis by STEM/EDX verified the elemental composition of cit-AgNP (Figure S1).

\subsection{Toxicity of silver compounds depends on media composition}

The cit-AgNP toxicity was initially studied by measuring the viability of polarized RTgutGC cells after $24 \mathrm{hrs}$ of exposure to either $\mathrm{AgNO}_{3}$ or cit-AgNP at various equivalent silver concentrations and in two exposure media, in L-15/ex and L-15/FBS. Viability of RTL-W1 cultured under RTgutGC was also evaluated. For the sake of simplicity, we chose to express all our data, $\mathrm{AgNO}_{3}$ and citAgNP exposures, in equivalents of total silver, in $\mu \mathrm{M}$, (Figure 2).

While silver nitrate is more toxic than cit-AgNP in L15/ex (5 and 22-fold when considering lysosome integrity or metabolic activity, respectively), an opposite scenario is shown when exposing cells in L-15/FBS (Table S1, Figure 2). This effect can be attributed to the scavenging properties of 


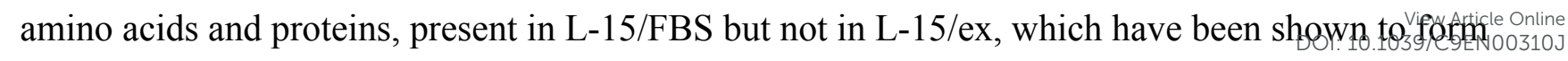
thiolate complexes with silver ions ${ }^{5}$. Therefore, the exposure medium has an important role in mediating the toxicity of dissolved silver, but less so in mediating the toxicity of cit-AgNP. Silver NPs can enter the cell via endocytosis and release silver ions into intracellular vesicles such as lysosomes $5,32,36,45,54$ thus, reducing the scavenging effect of amino acids and proteins. In support of this hypothesis, lysosome membrane integrity measured via the Neutral Red assay is significantly more sensitive than metabolic activity in RTgutGC exposed to cit-AgNP (Figure 2 and $^{39}$ ). RTL-W1 exposed to cit-AgNP seeded in the basolateral chamber (under the polarized RTgutGC) were little impacted with a statistically significant reduction in viability of about 20 and $30 \%$ in metabolic activity only in cells exposed to 100 and $500 \mu \mathrm{M}$ of cit-AgNP, respectively. Moreover, the response of RTL-W1 was similar to RTgutGC exposed to $\mathrm{AgNO}_{3}$, where the metabolic activity endpoint was more sensitive than lysosome integrity suggesting that ionic silver was the major cause of cytotoxicity.

According to the cell viability data, $1 \mu \mathrm{M}$ of $\mathrm{AgNO}_{3}$ or cit-AgNP was non-toxic for RTgutGC cells in both exposure media. A reduction of about 20\% (EC20) in lysosome integrity was observed at 3.4 $\mu \mathrm{M}$ of $\mathrm{AgNO}_{3}$ or $10 \mu \mathrm{M}$ of cit-AgNP in L-15/ex. These exposure concentrations were selected to evaluate silver uptake and transcriptional responses in RTgutGC.

\subsection{Uptake of silver nitrate and cit-AgNP}

Uptake of silver in RTgutGC is independent of the silver form (i.e. ionic or nano) but is dependent on the exposure media type (i.e. L-15/FBS or L-15/ex) (Figure 3 and Table 1). RTgutGC exposed to $1 \mu \mathrm{M}$ of silver equivalent in ionic- $\left(\mathrm{AgNO}_{3}\right)$ or nano- (cit-AgNP) form accumulated comparable levels of intracellular silver. However, exposures in L-15/ex resulted in a higher accumulation of silver ( 3-fold, for both $\mathrm{AgNO}_{3}$ or cit-AgNP) when compared to exposures in L-15/FBS (Figure 3, 
Table 1). This effect is attributable to the stabilizing properties of FBS that resulted in less citiexand precipitation and by cysteine complexation with $\mathrm{Ag}$ ions that might reduce uptake . $^{5}$

Previous studies have shown that AgNP are able to enter epithelial cells and accumulate into cellular vesicle-like structures including lysosomes ${ }^{32,55-58}$. In this study cit-AgNP entered and accumulated in RTgutGC cells in a dose dependent manner as indicated by ICP-MS analysis (Figure 3A). However, nanoparticulate silver was detectable by STEM/EDX in a vesicle-like structure only in cells exposed for $3 \mathrm{hrs}$. In cells exposed for $24 \mathrm{hrs}$, nanoparticulate silver was not detectable by EDX (Figure 4; Figure S2). Therefore, our results support previous studies showing that AgNP can exert toxicity using the "Trojan horse" mechanism and dissolve rapidly intracellularly $35,58,59$. Using an innovative approach that combined microscopy and X-ray absorption spectroscopy, Veronesi and coauthors $^{58}$, have shown that in hepatocytes following $24 \mathrm{hrs}$ exposure to cit-AgNP, around $50 \%$ of silver was in nano-form $\left(\mathrm{Ag}^{0}\right)$ and the remaining dissolved silver was complexed mainly to glutathione.

In addition, $\mathrm{AgNO}_{3}$ appears to be transported across the RTgutGC epithelium into the basolateral chamber and absorbed by RTL-W1 cells more efficiently than cit-AgNP (Figure 3).

\subsection{Intracellular effects of silver nitrate and cit-AgNP on metal homeostasis}

RTgutGC cells exposed to toxic concentrations (EC20) of silver nitrate showed a marked reduction in the intracellular essential trace elements, zinc and iron, and possibly also copper (though not statistically significant; Table 1). This reduction in intracellular essential trace metals could be due to the activation of the Metal regulatory Transcription Factor 1 (MTF1) by intracellular silver ${ }^{60,61}$, which has been shown to induce several essential metal excretory proteins, including the zinc transporter 1 (ZnT1), the iron-regulated transporter 1 (IREG1 or ferroportin-1) and the copper ATPase (ATP7A) ${ }^{62}$. Induction of ZnT1 was also measured in this study in RTgutGC cells, along with Metallothionein b (MTb), another target gene of MTF1, supporting the hypothesis that excess 
intracellular silver activates MTF1 (Figure 5). Alteration of copper homeostasis was moreovediew Article Online shown at the post-translational level via the monitoring of ATP7A trafficking in Caco2 cells (Figure 6). ATP7A is a pivotal protein in the regulation of cellular $\mathrm{Cu}$ homeostasis responsible for normal delivery of $\mathrm{Cu}$ to cupro-enzymes, occurring at the TGN, and excretion of $\mathrm{Cu}$ in conditions of excess $\mathrm{Cu}$, occurring at the cell periphery. ATP7A was also shown to traffic to the cell periphery in response to intracellular silver excess ${ }^{63}$. ATP7A cellular location is therefore indicative of intracellular $\mathrm{Cu}$ and $\mathrm{Ag}$ availability ${ }^{64,65}$. It is therefore understandable why the trafficking of ATP7A is so important for its function and for the regulation of intracellular copper homeostasis. Indeed, in Menkes disease, defective ATP7A proteins lose their trafficking properties ${ }^{64}$. In this study, the ratio of ATP7A co-localizing with the TGN or with actin as marker of cell periphery was lower in cells exposed to $\mathrm{CuSO}_{4}$, used as a positive control' ${ }^{21}$, and $\mathrm{AgNO}_{3}$ (Figure 6). This indicates a more peripheral localization of ATP7A as expected in conditions of intracellular copper or silver excess $^{21,65}$. ATP7A also co-localized toward the periphery in cells exposed to cit-AgNP, although less than in cells exposed to $\mathrm{AgNO}_{3}$. The ratios of co-localization of ATP7A with actin divided by the ratio of ATP7A with TGN were 3.0 and 1.8 for cit-AgNP and $\mathrm{AgNO}_{3}$, respectively. A similar response, i.e. induction of trafficking of copper ATPases, was shown in human hepatocytes (HepG2) exposed to copper oxide $\mathrm{NP}^{66}$, indicating that copper or silver NPs can induce the trafficking of these proteins in response to excess intracellular metal concentrations. Such response, induction of copper excretion via ATP7A trafficking, could explain the reduced serum copper and ceruloplasmin in human ingesting colloidal silver ${ }^{67}$.

Measurement of MTb mRNA levels were an excellent marker of intracellular silver bio-reactivity (i.e. induction of a biological response; Figure 5). RTgutGC exposed to $1 \mu \mathrm{M}$ silver equivalent $\left(\mathrm{AgNO}_{3}\right.$ or cit-AgNP) accumulated similar amounts of silver (Table 1). However, $\mathrm{AgNO}_{3}$ exposed cells expressed about twice as much MTb mRNA levels than cells exposed to cit-AgNP (Figure 5) suggesting that cit-AgNP might be accumulated in a less bio-reactive form, i.e. metallic $\mathrm{Ag}^{0}$, and 
remain in a non-bio-reactive form until dissolution occurs. The induction of MTb by cit-AgNos likely occurs following dissolution into lysosomes which in turn results in lysosome damage ${ }^{5}$ and leakage of silver into the cytoplasm. Extracellular dissolution of cit-AgNP, estimated at 2\% in L15/ex ${ }^{45}$, likely has a negligible effect on RTgutGC. Exposure to $200 \mathrm{nM}$ of $\mathrm{AgNO}_{3}$, an equivalent amount of silver dissolved from $10 \mu \mathrm{M}$ of cit-AgNP, did not induce MTb expression (Figure 5). MTb was also induced 6.3-fold in RTL-W1 under RTgutGC exposed to $3.4 \mu \mathrm{M} \mathrm{AgNO}_{3}$ in L-15/ex (Figure S4). This is in agreement with the higher transport of Ag to the basolateral compartment in these inserts (Figure 3). Excluding MTb, all other genes measured were not changed in their mRNA abundance compared to controls in RTL-W1 (not shown). The mRNA level of other genes involved in metal detoxification and homeostasis processes were measured, and in addition to MTb and ZnT1 also glutathione reductase (GR) was induced in cells exposed to $3.4 \mu \mathrm{M}$ of $\mathrm{AgNO}_{3}$ in $\mathrm{L}-15 / \mathrm{ex}$ and 1 $\mu \mathrm{M}$ of $\mathrm{AgNO}_{3}$ and cit-AgNP in L-15/FBS, indicating an oxidative response. Messenger RNA of transporter proteins Divalent Metal Transporter 1, ATP7A and Na/K-ATPase (NAK) were not affected at the mRNA level in RTgutGC (Figure 5). In summary, cit-AgNP accumulated in RTgutGC cells, disrupting lysosome membrane integrity and increasing MTb mRNA levels, but did not induce a significant disruption of essential metal homeostasis as both intracellular essential metals and ATP7A trafficking were not significantly different from controls.

\section{Conclusions}

We reveal that silver is a potent disruptor of essential metal homeostasis. RTgutGC cells exposed to toxic concentrations of silver nitrate displayed a reduction in intracellular zinc, iron and copper. We hypothesized that this reduction might be due to the induction of MTF1 target genes including the zinc exporter ZnT1 and the copper exporter, ATP7A. Indeed, an increase of ZnT1 mRNA levels was shown in RTgutGC cells exposed to silver nitrate. Furthermore, we show that ATP7A function is 
induced, at the posttranslational level, by silver nitrate and by cit-AgNP, although the latter totex $_{9}$ Article Online smaller extent. RTgutGC accumulated similar amounts of silver following exposure to equivalent amounts of total silver in cit-AgNP or $\mathrm{AgNO}_{3}$ form. However, the latter was a more potent inducer of Metallothionein, and of the oxidative stress marker glutathione reductase as well as ZnT1 mRNA levels and of ATP7A protein trafficking. All together, these transcriptional responses in RTgutGC cells and ATP7A trafficking responses in Caco2 cells indicate that, in these intestinal cells, nanoparticulate silver exert a similar but attenuated response to ionic silver $\left(\mathrm{AgNO}_{3}\right)$. Metallic silver $\left(\mathrm{Ag}^{0}\right)$ present in cit-AgNP might therefore not be bio-reactive until it is dissolved and leaks out of lysosomes. Furthermore, our viability and electron microscopy data show that cit-AgNP targets lysosomes.

The enterohepatic fish cell in vitro system allowed to elucidate of the effect of $\mathrm{AgNO}_{3}$ and cit- $\mathrm{AgNP}$ in liver cells following the intestinal cells uptake and processing. Overall, the intestinal cell protected the liver cells from acute toxicity but did not prevent the transport of silver ions into the basolateral chamber. We believe that this novel in vitro system will be a useful tool for fish nutrition and toxicology.

Disturbance of essential metal homeostasis has been linked to several human diseases including neurodegenerative disease ${ }^{68-70}$ and metabolic diseases ${ }^{71,72}$. Although such diseases are unknown in fish, disturbances of essential metal homeostasis have been shown to affect fish development and reproduction ${ }^{73-75}$ which could adversely affect fish populations. The disturbance of essential metal homeostasis by silver and AgNP should therefore also be considered in situations of lowconcentration, chronic exposures for the protection of both human and environmental health.

\section{Acknowledgments}

M.M. was funded by a Marie Curie Fellowship (IEF, No 275135) and by Eawag. The authors wish to 


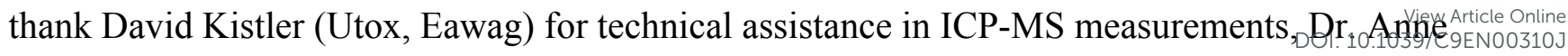
Greet Bittermann and Dr. Eszter Barthazy (ETHZ) for assistance in electron microscopy and Dr Adam Southon (Melbourne University) for the ATP7A antibody.

\section{References}

1 D. J. McClements and H. Xiao, Is nano safe in foods? Establishing the factors impacting the gastrointestinal fate and toxicity of organic and inorganic food-grade nanoparticles, npj Sci. Food, 2017, 1, 6.

2 S. H. S. Dananjaya, G. I. Godahewa, R. G. P. T. Jayasooriya, J. Lee and M. De Zoysa, Antimicrobial effects of chitosan silver nano composites (CAgNCs) on fish pathogenic Aliivibrio (Vibrio) salmonicida, Aquaculture, 2016, 450, 422-430.

3 P. Swain, S. K. Nayak, A. Sasmal, T. Behera, S. K. Barik, S. K. Swain, S. S. Mishra, A. K. Sen, J. K. Das and P. Jayasankar, Antimicrobial activity of metal based nanoparticles against microbes associated with diseases in aquaculture, World J. Microbiol. Biotechnol., 2014, 30, 2491-2502.

4 G. V. Lowry, B. P. Espinasse, A. R. Badireddy, C. J. Richardson, B. C. Reinsch, L. D. Bryant, A. J. Bone, A. Deonarine, S. Chae, M. Therezien, B. P. Colman, H. Hsu-Kim, E. S. Bernhardt, C. W. Matson and M. R. Wiesner, Long-term transformation and fate of manufactured Ag nanoparticles in a simulated large scale freshwater emergent wetland, Environ. Sci. Technol., 2012, 46, 7027-7036.

5 M. Minghetti and K. Schirmer, Effect of media composition on bioavailability and toxicity of silver and silver nanoparticles in fish intestinal cells (RTgutGC), Nanotoxicology, 2016, 10, $1526-1534$.

6 R. Behra, L. Sigg, M. J. D. Clift, F. Herzog, M. Minghetti, B. Johnston, A. Petri-Fink, B. 


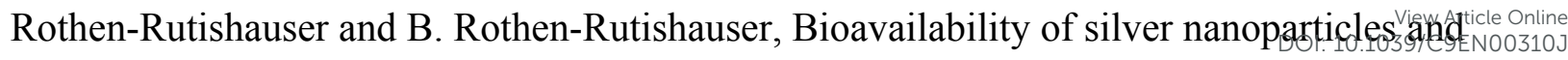
ions : from a chemical and biochemical perspective, J. R. Soc. Interface, 2013, 10, 20130396.

7 R. de Lima, A. B. Seabra and N. Durán, Silver nanoparticles: a brief review of cytotoxicity and genotoxicity of chemically and biogenically synthesized nanoparticles, J. Appl. Toxicol., 2012, 32, 867-79.

8 C. Zhang, Z. Hu and B. Deng, Silver nanoparticles in aquatic environments: Physiochemical behavior and antimicrobial mechanisms, Water Res., 2016, 88, 403-427.

9 S. Kim and D. Y. Ryu, Silver nanoparticle-induced oxidative stress, genotoxicity and apoptosis in cultured cells and animal tissues, J. Appl. Toxicol., 2013, 33, 78-89.

J. Han, S. Gurunathan, J.-K. Jeong, Y.-J. Choi, D.-N. Kwon, J.-K. Park and J.-H. Kim, Oxidative stress mediated cytotoxicity of biologically synthesized silver nanoparticles in human lung epithelial adenocarcinoma cell line, Nanoscale Res. Lett., 2014, 9, 459.

11 M. Srivastava, S. Singh and W. T. Self, Exposure to Silver Nanoparticles Inhibits Selenoprotein Synthesis and the Activity of Thioredoxin Reductase, Enviromental Heal. Perspect., 2012, 120, 56-61.

12 M. van der Zande, A. K. Undas, E. Kramer, M. P. Monopoli, R. J. Peters, D. Garry, E. C. Antunes Fernandes, P. J. Hendriksen, H. J. Marvin, A. A. Peijnenburg and H. Bouwmeester, Different responses of Caco-2 and MCF-7 cells to silver nanoparticles are based on highly similar mechanisms of action, Nanotoxicology, 2016, 10, 1431-1441.

13 M. M. Cortese-Krott, M. Münchow, E. Pirev, F. Hessner, A. Bozkurt, P. Uciechowski, N. Pallua, K.-D. Kröncke and C. V Suschek, Silver ions induce oxidative stress and intracellular zinc release in human skin fibroblasts, Free Radic. Biol. Med., 2009, 47, 1570-7.

14 F. Benetti, L. Bergoli, I. Olivato and E. Sabbioni, Effects of metal(lodi)-based nanomaterials on essential elements homeostasis: The central role of nanometallomics for nanotoxicology, 
15 M. Chevallet, G. Veronesi, A. Fuchs, E. Mintz, I. Michaud-Soret and A. A. Deniaud, Impact of labile metal nanoparticles on cellular homeostasis. Current developments in imaging, synthesis and applications, Biochim. Biophys. Acta - Gen. Subj., 2017, 1861, 1566-1577.

16 E. J. Martinez-Finley, S. Chakraborty, S. J. B. Fretham and M. Aschner, Cellular transport and homeostasis of essential and nonessential metals, Metallomics, 2012, 4, 593-605.

17 J. Lee, M. M. Pena, Y. Nose, D. J. Thiele and M. M. O. Peña, Biochemical Characterization of the Human Copper Transporter Ctr1, J. Biol. Chem., 2002, 277, 4380-4387.

18 J. Bertinato, L. Cheung, R. Hoque and L. J. Plouffe, Ctr1 transports silver into mammalian cells, J. Trace Elem. Med. Biol., 2010, 24, 178-184.

M. Solioz, A. Odermatt and A. Solioz, Marc; Odermatt, Copper and Silver Transport by CopB-ATPase in Membrane Vesicles of Enterococcus hirae, J. Biol. Chem., 1995, 270, $9217-$ 9221.

20 N. R. Bury, M. Grosell, A. K. Grover and C. M. Wood, ATP-dependent silver transport across the basolateral membrane of rainbow trout gills, Toxicol. Appl. Pharmacol., 1999, 159, 1-8.

21 L. Pase, I. Voskoboinik, M. Greenough and J. Camakaris, Copper stimulates trafficking of a distinct pool of the Menkes copper ATPase (ATP7A) to the plasma membrane and diverts it into a rapid recycling pool, Biochem. J., 2004, 378, 1031-7.

22 S. R. Hanson, S. A. Dontey and M. C. Linder, Transport of silver in virgin and lactating rats and relation to copper, J. trace Elem. Med. bilogy, 2001, 15, 243-253.

23 F. Hirasawa, Y. Kawarada, M. Sato, S. Suzuki, K. Terada, N. Miura, M. Fujii, K. Kato, Y. Takizawa and T. Sugiyama, The effect of silver administration on the biosynthesis and the molecular properties of rat ceruloplasmin, Biochim. Biophys. Acta - Gen. Subj., 1997, 1336, 
195-201.

24 E. Ilyechova, A. Skvortsov, E. Zatulovsky, N. Tsymbalenko, M. Shavlovsky, M. Broggini and L. Puchkova, Experimental switching of copper status in laboratory rodents, J. Trace Elem. Med. Biol., 2011, 25, 27-35.

W. Liu, I. A. M. Worms, N. Herlin-Boime, D. Truffier-Boutry, I. Michaud-Soret, E. Mintz, C. Vidaud and F. Rollin-Genetet, Interaction of silver nanoparticles with metallothionein and ceruloplasmin: Impact on metal substitution by $\mathrm{Ag}(\mathrm{i})$, corona formation and enzymatic activity, Nanoscale, 2017, 9, 6581-6594.

26 J. A. Roe, R. Peoples, D. M. Scholler and J. S. Valentine, Silver-binding properties of bovine cuprozinc superoxide dismutase and the overall stability of selected metal-ion derivatives, $J$. Am. Chem. Soc., 1990, 112, 1538-1545.

27 M. R. Ciriolo, P. Civitareale, M. T. Carrì, A. De Martino, F. Galiazzo and G. Rotilio, Purification and characterization of Ag,Zn-superoxide dismutase from Saccharomyces cerevisiae exposed to silver, J. Biol. Chem., 1994, 269, 25783-25787.

V. A. Kostevich, A. V. Sokolov, S. O. Kozlov, A. Y. Vlasenko, N. N. Kolmakov, E. T. Zakharova and V. B. Vasilyev, Functional link between ferroxidase activity of ceruloplasmin and protective effect of apo-lactoferrin: studying rats kept on a silver chloride diet, BioMetals, 2016, 29, 691-704.

29 N. R. Bury and C. M. Wood, Mechanism of branchial apical silver uptake by rainbow trout is via the proton-coupled $\mathrm{Na}^{+}$channel, Am. J. Physiol. Regul. Integr. Comp. Physiol., 1999, 277, R1385-R1391.

I. J. Morgan, R. P. Henry and Wood Chris M., The mechanism of acute silver nitrate toxicity in freshwater rainbow trout (Oncorhynchus mykiss) is inhibition of gill $\mathrm{Na}+$ and $\mathrm{Cl}-1$ transport, Aquat. Toxicol., 1997, 38, 145-163. 


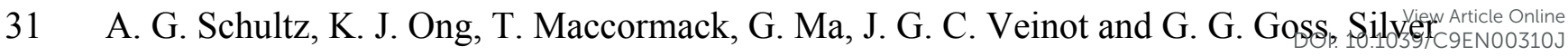
Nanoparticles Inhibit Sodium Uptake in Juvenile Rainbow Trout (Oncorhynchus mykiss), Environ. Sci. Technol., 2012, 46, 10295-301.

32 Y. Yue, R. Behra, L. Sigg, M. J.-F. Suter, S. Pillai and K. Schirmer, Silver nanoparticleprotein interactions in intact rainbow trout gill cells, Environ. Sci. Nano, 2016, 3, 1174-1185.

33 M. Minghetti, M. J. Leaver, E. Carpenè, S. G. George, E. Carpene and S. G. George, Copper transporter 1, metallothionein and glutathione reductase genes are differentially expressed in tissues of sea bream (Sparus aurata) after exposure to dietary or waterborne copper, Comp. Biochem. Physiol. Part C Toxicol. Pharmacol., 2008, 147, 450-459.

34 M. Minghetti, M. J. Leaver and S. G. George, Multiple Cu ATPase genes are differentially expressed and transcriptionally regulated by $\mathrm{Cu}$ exposure in Sea bream, Sparus aurata, Aquat. Toxicol., 2010, 97, 23-33.

35 X. Jiang, T. Miclăuş, L. Wang, R. Foldbjerg, D. S. Sutherland, H. Autrup, C. Chen and C. Beer, Fast intracellular dissolution and persistent cellular uptake of silver nanoparticles in CHO-K1 cells: implication for cytotoxicity, Nanotoxicology, 2015, 9, 181-189.

36 M. I. Setyawati, X. Yuan, J. Xie and D. T. Leong, The influence of lysosomal stability of silver nanomaterials on their toxicity to human cells, Biomaterials, 2014, 35, 6707-15.

37 S. Bastian, W. Busch, D. Kuhnel, A. Springer, T. Meissner, R. Holke, S. Scholz, M. Iwe, W. Pompe, M. Gelinsky, W. Potthoff, V. Richter, C. Ikonomidou and K. Schirmer, Toxicity of tungsten carbide and cobalt-doped tungsten carbide nanoparticles in mammalian cells in vitro, Enviromental Heal. Perspect., 2009, 117, 530-536.

38 E. Navarro, F. Piccapietra, B. Wagner, F. Marconi, R. Kaegi, N. Odzak, L. Sigg and R. Behra, Toxicity of Silver Nanoparticles to Chlamydomonas reinhardtii, Environ. Sci. Technol., 2008, 42, 8959-8964. 


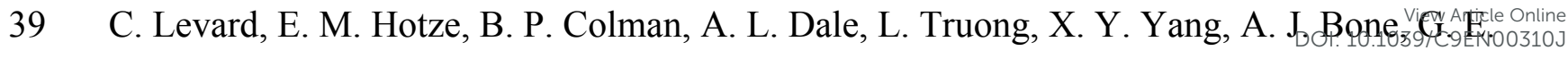
Brown, R. L. Tanguay, R. T. Di Giulio, E. S. Bernhardt, J. N. Meyer, M. R. Wiesner and G. V. Lowry, Sulfidation of silver nanoparticles: Natural antidote to their toxicity, Environ. Sci. Technol., 2013, 47, 13440-13448.

40 M. Auffan, C. W. Matson, J. Rose, M. Arnold, O. Proux, B. Fayard, W. Liu, P. Chaurand, M. R. Wiesner, J.-Y. Bottero and R. T. Di Giulio, Salinity-dependent silver nanoparticle uptake and transformation by Atlantic killifish (Fundulus heteroclitus) embryos, Nanotoxicology, $2014,8,167-176$.

41 A. Kawano, C. Haiduk, K. Schirmer, R. Hanner, L. E. J. E. J. Lee, B. Dixon and N. C. C. Bols, Development of a rainbow trout intestinal epithelial cell line and its response to lipopolysaccharide, Aquac. Nutr., 2011, 17, e241-e252.

M. Minghetti, C. Drieschner, N. Bramaz, H. Schug and K. Schirmer, A fish intestinal epithelial barrier model established from the rainbow trout (Oncorhynchus mykiss) cell line, RTgutGC, Cell Biol. Toxicol., 2017, 33, 539-555.

M. Geppert, L. Sigg and K. Schirmer, A novel two-compartment barrier model for investigating nanoparticle transport in fish intestinal epithelial cells, Environ. Sci. Nano, 2016, 3, 388-395.

L. E. Lee, J. H. Clemons, D. G. Bechtel, S. J. Caldwell, K. B. Han, M. Pasitschniak-Arts, D. D. Mosser and N. C. Bols, Development and characterization of a rainbow trout liver cell line expressing cytochrome P450-dependent monooxygenase activity, Cell Biol. Toxicol., 1993, 9, $279-94$.

Y. Yue, R. Behra, L. Sigg, P. Fernández Freire, S. Pillai and K. Schirmer, Toxicity of silver nanoparticles to a fish gill cell line: Role of medium composition, Nanotoxicology, 2015, 9, $54-63$. 
46 A. M. Zimnicka, K. Ivy and J. H. Kaplan, Acquisition of dietary copper: a role for aniøigh Article Online transporters in intestinal apical copper uptake, Am. J. Physiol. Cell Physiol., 2011, 300, C58899.

47 K. Schirmer, a. G. J. Chan, B. M. Greenberg, D. G. Dixon and N. C. Bols, Methodology for demonstrating and measuring the photocytotoxicity of fluoranthene to fish cells in culture, Toxicol. Vitr., 1997, 11, 107-119.

48 E. Borenfreund and J. A. Puerner, Toxicity determined in vitro by morphological alterations and neutral red absorption, Toxicol. Lett., 1985, 24, 119-124.

49 M. Geppert, M. C. Hohnholt, K. Thiel, S. Nürnberger, I. Grunwald, K. Rezwan and R. Dringen, Uptake of dimercaptosuccinate-coated magnetic iron oxide nanoparticles by cultured brain astrocytes, Nanotechnology, 2011, 22, 145101.

50 M. Minghetti, S. Schnell, M. A. Chadwick, C. Hogstrand and N. R. Bury, A primary FIsh Gill Cell System (FIGCS) for environmental monitoring of river waters, Aquat. Toxicol., 2014, 154, 184-192.

51 J. Vandesompele, K. De Preter, F. Pattyn, B. Poppe, N. Van Roy, A. De Paepe and F. Speleman, Accurate normalization of real-time quantitative RT-PCR data by geometric averaging of multiple internal control genes, Genome Biol., 2002, 3, research0034research0034.

52 I. Hamza, J. Prohaska and J. D. Gitlin, Essential role for Atox1 in the copper-mediated intracellular trafficking of the Menkes ATPase, Proc. Natl. Acad. Sci., 2003, 100, 1215-1220.

53 D. Kühnel, W. Busch, T. Meißner, A. Springer, A. Potthoff, V. Richter, M. Gelinsky, S. Scholz and K. Schirmer, Agglomeration of tungsten carbide nanoparticles in exposure medium does not prevent uptake and toxicity toward a rainbow trout gill cell line, Aquat. Toxicol., 2009, 93, 91-99. 
54 X. Jiang, T. Miclăuş, L. Wang, R. Foldbjerg, D. S. Sutherland, H. Autrup, C. Chen, andigêderticle Online Beer, Fast intracellular dissolution and persistent cellular uptake of silver nanoparticles in CHO-K1 cells: implication for cytotoxicity, Nanotoxicology, 2014, 5390, 1-9.

55 J. García-Alonso, F. R. Khan, S. K. Misra, M. Turmaine, B. D. Smith, P. S. Rainbow, S. N. Luoma and E. Valsami-Jones, Cellular internalization of silver nanoparticles in gut epithelia of the estuarine polychaete Nereis diversicolor, Environ. Sci. Technol., 2011, 45, 4630-6.

56 J. Farkas, P. Christian, J. A. Gallego-Urrea, N. Roos, M. Hassellöv, K. E. Tollefsen and K. V Thomas, Uptake and effects of manufactured silver nanoparticles in rainbow trout (Oncorhynchus mykiss) gill cells, Aquat. Toxicol., 2011, 101, 117-25.

57 M. Milić, G. Leitinger, I. Pavičić, M. Zebić Avdičević, S. Dobrović, W. Goessler and I. Vinković Vrček, Cellular uptake and toxicity effects of silver nanoparticles in mammalian kidney cells, J. Appl. Toxicol., 2014, n/a-n/a.

58 G. Veronesi, A. Deniaud, T. Gallon, P.-H. Jouneau, J. Villanova, P. Delangle, M. Carrière, I. Kieffer, P. Charbonnier, E. Mintz and I. Michaud-Soret, Visualization, quantification and coordination of $\mathrm{Ag}^{+}$ions released from silver nanoparticles in hepatocytes, Nanoscale, 2016, 8, 17012-17021.

59 I.-L. Hsiao, Y.-K. Hsieh, C.-F. Wang, I.-C. Chen and Y.-J. Huang, Trojan-horse Mechanism in the Cellular Uptake of Silver Nanoparticles Verified by Direct Intra- and Extracellular Silver Speciation Analysis, Enviromental Sci. Technol., 2015, 49, 3813-21.

60 P. A. Walker, P. Kille, A. Hurley, N. R. Bury and C. Hogstrand, An in vitro method to assess toxicity of waterborne metals to fish, Toxicol. Appl. Pharmacol., 2008, 230, 67-77.

61 R. D. Palmiter, Regulation of metallothionein genes by heavy metals appears to be mediated by a zinc-sensitive inhibitor that interacts with a constitutively active transcription factor, MTF-1, Proc. Natl. Acad. Sci. U. S. A., 1994, 91, 1219-1223. 


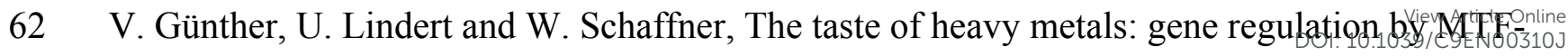
1, Biochim. Biophys. Acta, 2012, 1823, 1416-25.

63 M. J. Petris, F. J. Mercer, J. G. Culvenor, P. Lockhart, P. A. Glooson, J. Camakaris, J. F. Mercer and P. a Gleeson, Ligand-regulated transport of the Menkes copper P-type ATPase efflux pump from the Golgi apparatus to the plasma membrane: a novel mechanism of regulated trafficking, EMBO J., 1996, 15, 6084-6095.

64 S. Lutsenko, A. Gupta, J. L. Burkhead and V. Zuzel, Cellular multitasking: The dual role of human $\mathrm{Cu}-\mathrm{ATPases}$ in cofactor delivery and intracellular copper balance, Arch. Biochem. Biophys., 2008, 476, 22-32.

65 L. Nyasae, R. Bustos, L. Braiterman, B. Eipper and A. Hubbard, Dynamics of endogenous ATP7A (Menkes protein) in intestinal epithelial cells: copper-dependent redistribution between two intracellular sites, AJP - Gastrointest. Liver Physiol., 2007, 292, G1181-G1194.

66 M. Cuillel, M. Chevallet, P. Charbonnier, C. Fauquant, I. Pignot-Paintrand, J. Arnaud, D. Cassio, I. Michaud-Soret and E. Mintz, Interference of $\mathrm{CuO}$ nanoparticles with metal homeostasis in hepatocytes under sub-toxic conditions, 2014, 6, 1707-15.

67 K. M. Stepien and A. Taylor, Colloidal silver ingestion with copper and caeruloplasmin deficiency, Ann. Clin. Biochem., 2012, 49, 300-1.

68 D. J. Waggoner, T. B. Bartnikas, J. D. Gitlin and N. K. Bartnikas, The role of copper in neurodegenerative disease, Neurobiol. Dis., 1999, 6, 221-230.

69 S. A. Bellingham, B. Guo and A. F. Hill, The secret life of extracellular vesicles in metal homeostasis and neurodegeneration, Biol. Cell, 2015, 107, 389-418.

70 W. I. Vonk and L. W. Klomp, Role of transition metals in the pathogenesis of amyotrophic lateral sclerosis, Biochem. Soc. Trans., 2008, 36, 1322-1328. 


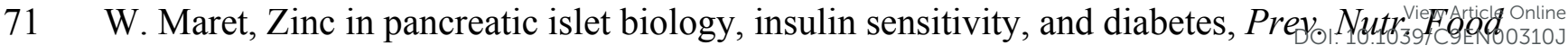
Sci., 2017, 22, 1-8.

72 A. Katsarou, S. Gudbjörnsdottir, A. Rawshani, D. Dabelea, E. Bonifacio, B. J. Anderson, L. M. Jacobsen, D. A. Schatz and Å. Lernmark, Type 1 diabetes mellitus, Nat. Rev. Dis. Prim., 2017, 3, 17016.

73 P. Couture and G. Pyle, Field Studies on Metal accumulation and effects in fish, in Homeostasis and Toxicology of Essential Metals, eds. C. M. Wood, A. P. Farrell and C. J. Brauner, Elsevier, 2012, pp. 417-473.

74 L. M. Beaver, L. Truong, C. L. Barton, T. T. Chase, G. D. Gonnerman, C. P. Wong, R. L. Tanguay and E. Ho, Combinatorial effects of zinc deficiency and arsenic exposure on zebrafish (Danio rerio) development, PLoS One, 2017, 12, 1-21.

75 M. K. Driessnack, A. Jamwal and S. Niyogi, Effects of chronic exposure to waterborne copper and nickel in binary mixture on tissue-specific metal accumulation and reproduction in fathead minnow (Pimephales promelas), Chemosphere, 2017, 185, 964-974. 
TABLES

Table 1: Intracellular metal content expressed as ng metal per mg of protein ${ }^{1}$.

\begin{tabular}{|c|c|c|c|c|}
\hline \multirow[b]{2}{*}{ RTgutGC } & \multicolumn{4}{|c|}{ Exposure in L-15/ex } \\
\hline & $\mathrm{Ag}$ & $\mathrm{Fe}$ & $\mathrm{Zn}$ & $\mathrm{Cu}$ \\
\hline Control & $<0.01$ & $55.0 \pm 1.24$ & $177 \pm 12.3$ & $4.00 \pm 0.58$ \\
\hline $\mathrm{AgNO}_{3} 1 \mu \mathrm{M}$ & $19.0 \pm 3.50^{\mathrm{b}}$ & $50.0 \pm 9.08$ & $156 \pm 11.7$ & $3.70 \pm 0.65$ \\
\hline $\mathrm{AgNO}_{3} 3.4 \mu \mathrm{M}$ & $54.0 \pm 11.4^{b}$ & $34.1 \pm 0.41 *$ & $120 \pm 24.6^{*}$ & $2.86 \pm 1.02$ \\
\hline cit-AgNP $1 \mu \mathrm{M}$ & $21.3 \pm 6.37^{b}$ & $51.5 \pm 8.30$ & $174 \pm 52.0$ & $3.60 \pm 0.77$ \\
\hline cit-AgNP $10 \mu \mathrm{M}$ & $313 \pm 104^{a}$ & $49.6 \pm 3.69$ & $169 \pm 19.8$ & $3.64 \pm 1.16$ \\
\hline \multicolumn{5}{|l|}{ RTL-W1 } \\
\hline Control & $<0.01$ & $107 \pm 40.4$ & $190 \pm 40.6$ & $5.52 \pm 0.49$ \\
\hline $\mathrm{AgNO}_{3} 1 \mu \mathrm{M}$ & $6.67 \pm 5.79^{b}$ & $91.7 \pm 50.9$ & $165 \pm 63.7$ & $7.45 \pm 4.29$ \\
\hline $\mathrm{AgNO}_{3} 3.4 \mu \mathrm{M}$ & $32.3 \pm 16.7^{a}$ & $106 \pm 54.8$ & $218 \pm 36.7$ & $5.96 \pm 2.26$ \\
\hline cit-AgNP $1 \mu \mathrm{M}$ & $1.69 \pm 0.61^{b}$ & $75.3 \pm 16.2$ & $137 \pm 13.7$ & $5.68 \pm 1.31$ \\
\hline \multirow[t]{2}{*}{ cit-AgNP $10 \mu \mathrm{M}$} & $6.74 \pm 3.69^{b}$ & $79.0 \pm 39.7$ & $173 \pm 14.3$ & $4.50 \pm 0.81$ \\
\hline & \multicolumn{4}{|c|}{ Exposure in L-15/FBS } \\
\hline RTgutGC & $\mathrm{Ag}$ & $\mathrm{Fe}$ & $\mathrm{Zn}$ & $\mathrm{Cu}$ \\
\hline Control & $<0.01$ & $45.0 \pm 1.4$ & $77.7 \pm 47.3$ & $3.1 \pm 2.2$ \\
\hline $\mathrm{AgNO}_{3} 1 \mu \mathrm{M}$ & $6.45 \pm 1.65$ & $36.1 \pm 19.3$ & $64.2 \pm 31.4$ & $3.4 \pm 2.4$ \\
\hline cit-AgNP $1 \mu \mathrm{M}$ & $7.37 \pm 7.32$ & $34.4 \pm 25.4$ & $63.4 \pm 33.1$ & $3.8 \pm 2.8$ \\
\hline
\end{tabular}

${ }^{1}$ Metal concentration in cell lysates is reported as ng metal per mg of protein determined from the same samples to take into account differences in cell numbers. Values represent mean \pm SD from three or four independent experiments, $\mathrm{N}=3$ or 4 . Statistical comparisons are within each metal. For $\mathrm{Ag}$, values bearing different lettering are significantly different $(\mathrm{P}<0.05,1$-way ANOVA, Tukey test). For other metals, asterisk indicate difference from respective silver-free control $(\mathrm{P}<0.05,1$ way ANOVA, Dunnet test). 
FIGURES

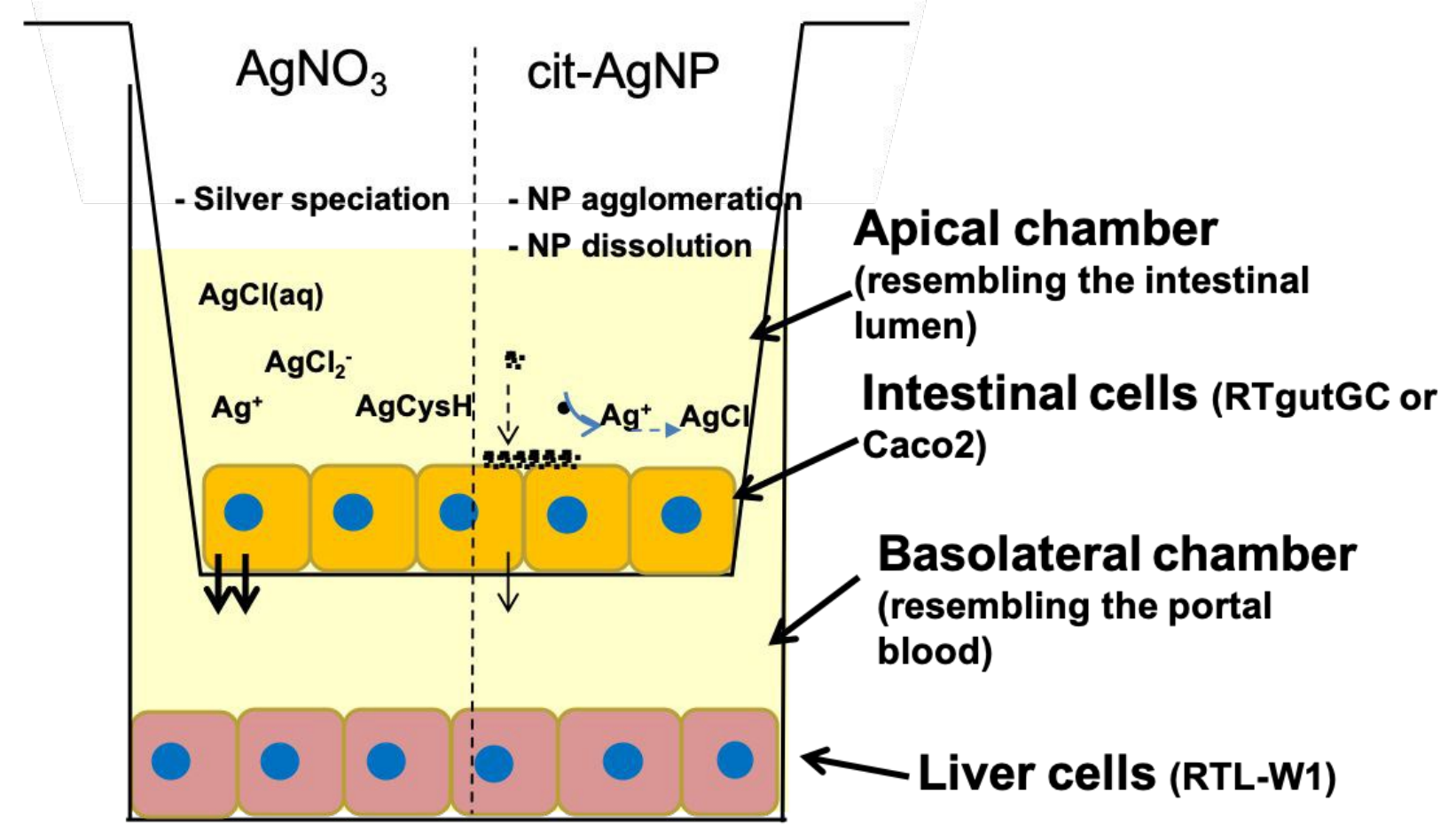

Figure 1: Schematic representation of the experimental system. Shown in the apical chamber are the factors influencing $\mathrm{Ag}$ bioavailability for $\mathrm{AgNO}_{3}$ and cit-AgNP (Derived from ${ }^{5,45}$ ). 


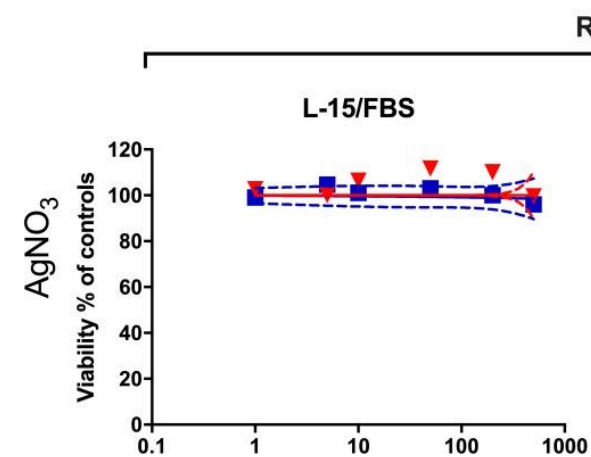

RTgutGC
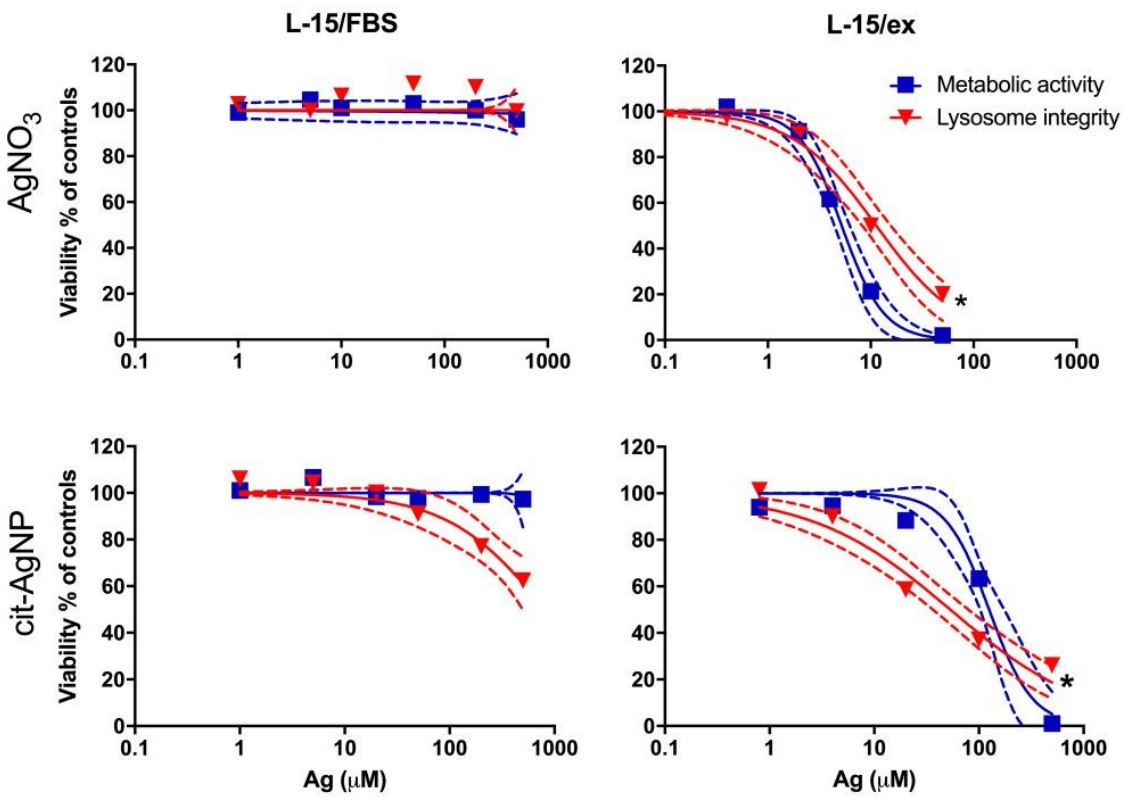

RTL-W1

Figure 2: Toxicity of $\mathrm{AgNO}_{3}$ and cit-AgNP as function of total silver in exposure media (L-15/FBS and L-15/ex). The endpoints measured, metabolic activity (Alamar blue) and lysosome integrity (Neutral Red), were recorded after 24 hrs of exposure. Values shown are averages and 95\% confidence intervals (dashed lines) of three independent experiments $(\mathrm{N}=3)$. RTL-W1 cells, sitting in the basolateral chamber, were exposed to cit-AgNP in L15/ex RTgutGC cells seeded on permeable membranes in the apical chamber. EC50s (shown in Table S1) were determined by the non-linear regression sigmoidal dose-response curve fitting module using the Hill slope equation. Asterisk indicate difference between curves assessed by F-test (GraphPad Prism Ver. 5.0, San Diego, CA). 


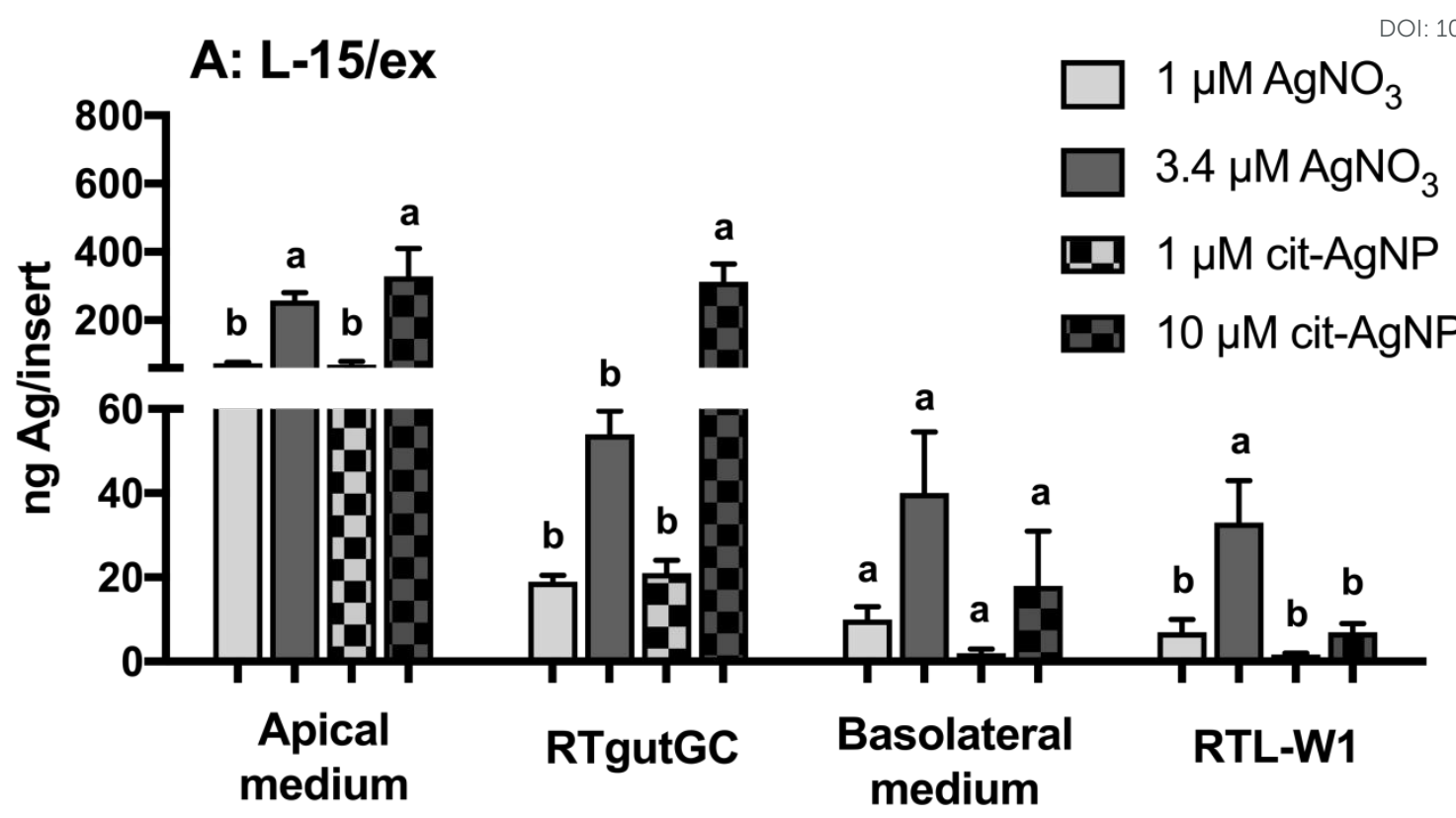

B: L-15/FBS

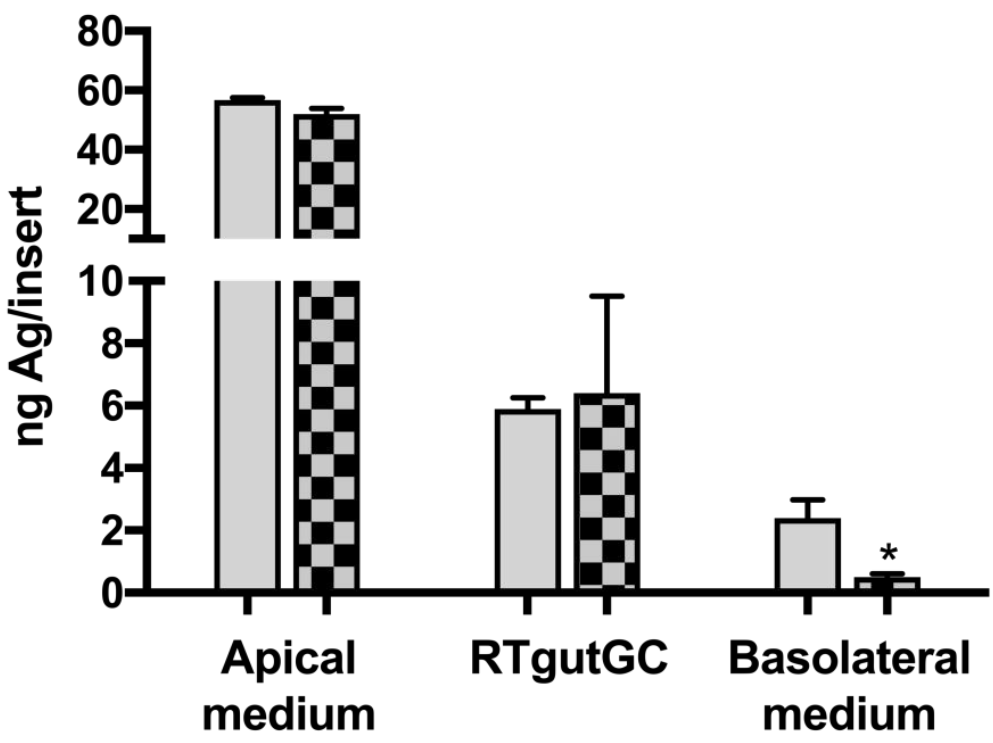

Figure 3: Silver determination by ICP-MS in (A) RTgutGC/RTL-W1 cell culture system (see Figure 1) exposed to $\mathrm{AgNO}_{3}$ or cit-AgNP in L-15/ex for $24 \mathrm{hrs}$. Values represent mean $\pm \mathrm{SD}$ from three or four independent experiments, $\mathrm{N}=3$ or 4 Bars bearing different lettering are significantly different (P<0.05, 1 way ANOVA, Tuckey test) and (B) RTgutGC cells system (without RTL-W1) exposed to $\mathrm{AgNO}_{3}$ or cit-AgNP in L-15/FBS for 24 hrs. Asterisk indicate statistical differences within groups (t-test, $\mathrm{p}<0.05)$. 

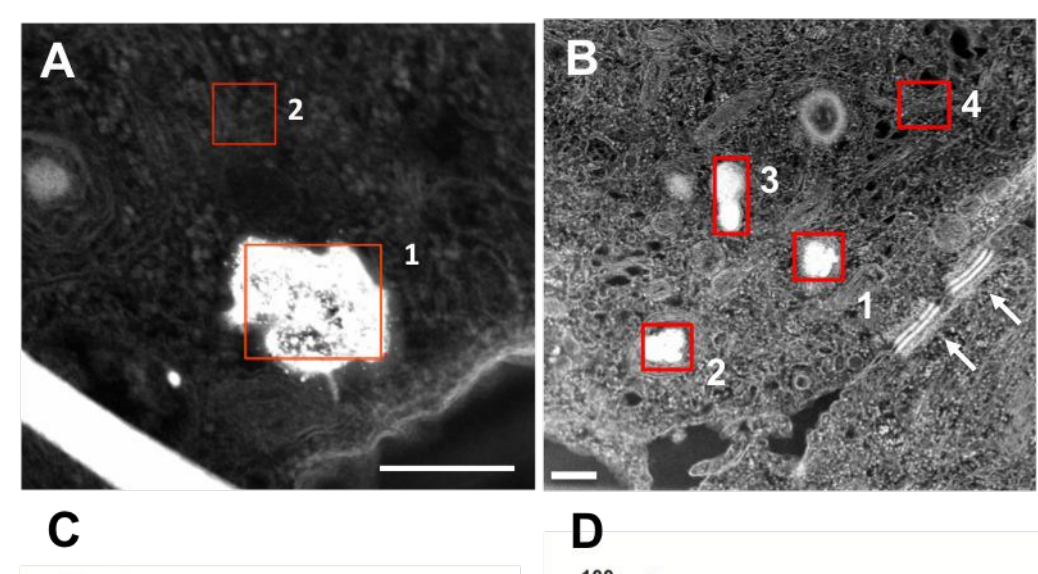

View Article Online DOI: $10.1039 /$ C9EN00310J

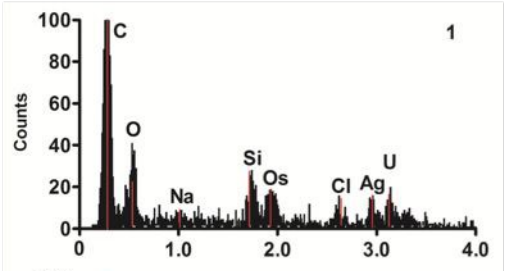

D
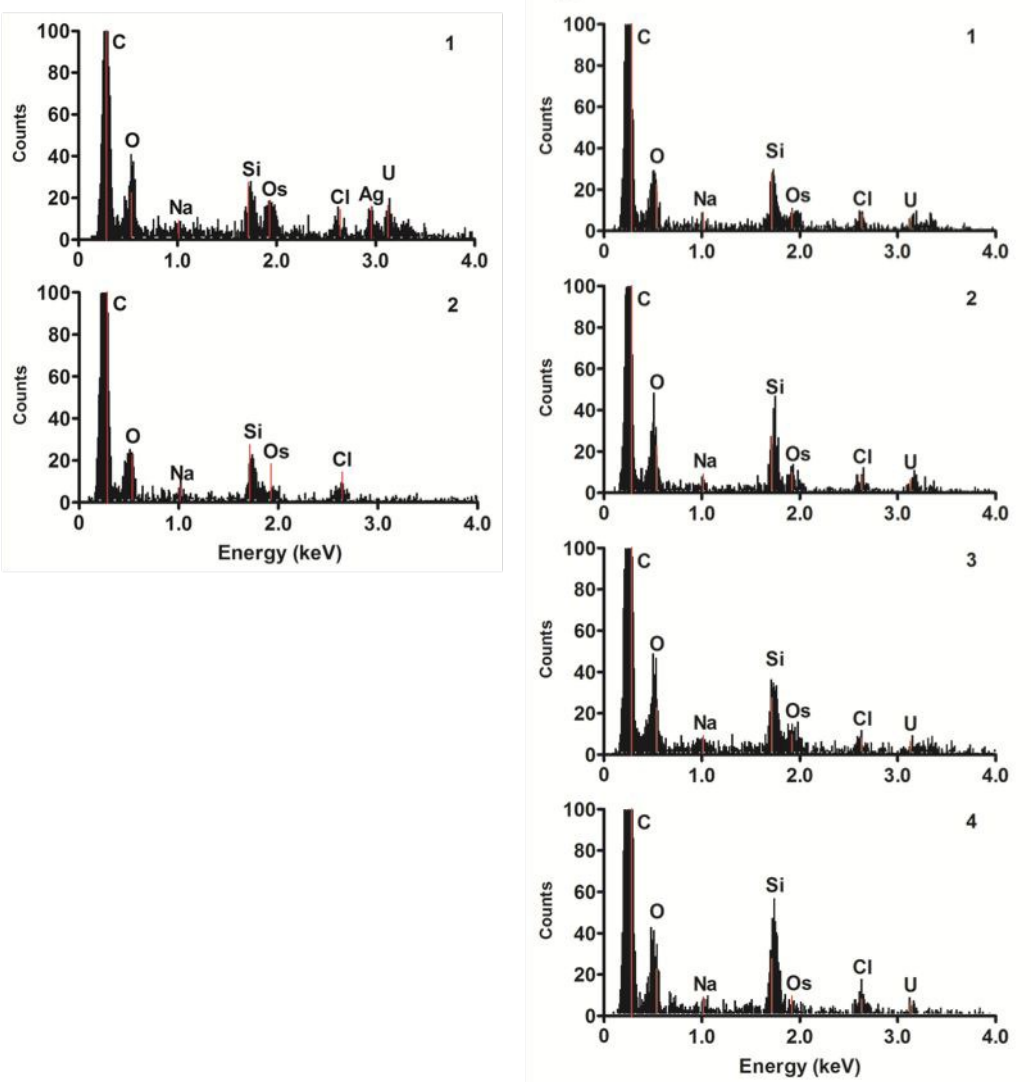

Figure 4: STEM images and EDX spectra of RTgutGC cells exposed to cit-AgNPs. (A) STEM image of RTgutGC cells exposed for 3 hrs to $50 \mu \mathrm{M}$ cit-AgNP in L-15/ex, the corresponding EDX spectra is shown in panel (C). Elemental Ag is shown in area 1, in a vesicle near the plasma membrane. Area 2 shows the spectra of the background. (B) STEM image of RTgutGC exposed for $24 \mathrm{hrs}$ to $10 \mu \mathrm{M}$ cit-AgNP in L-15/ex, the corresponding EDX spectra is shown in panel (D).

Elemental Ag was not detectable in any of the electron dense areas (1-3) at this later time point. Area 4 shows the spectra of the background. In panel B, a lysosome is enclosing area 2, arrows indicate desmosomes. Scale bar is $300 \mathrm{~nm}$ in both images. 

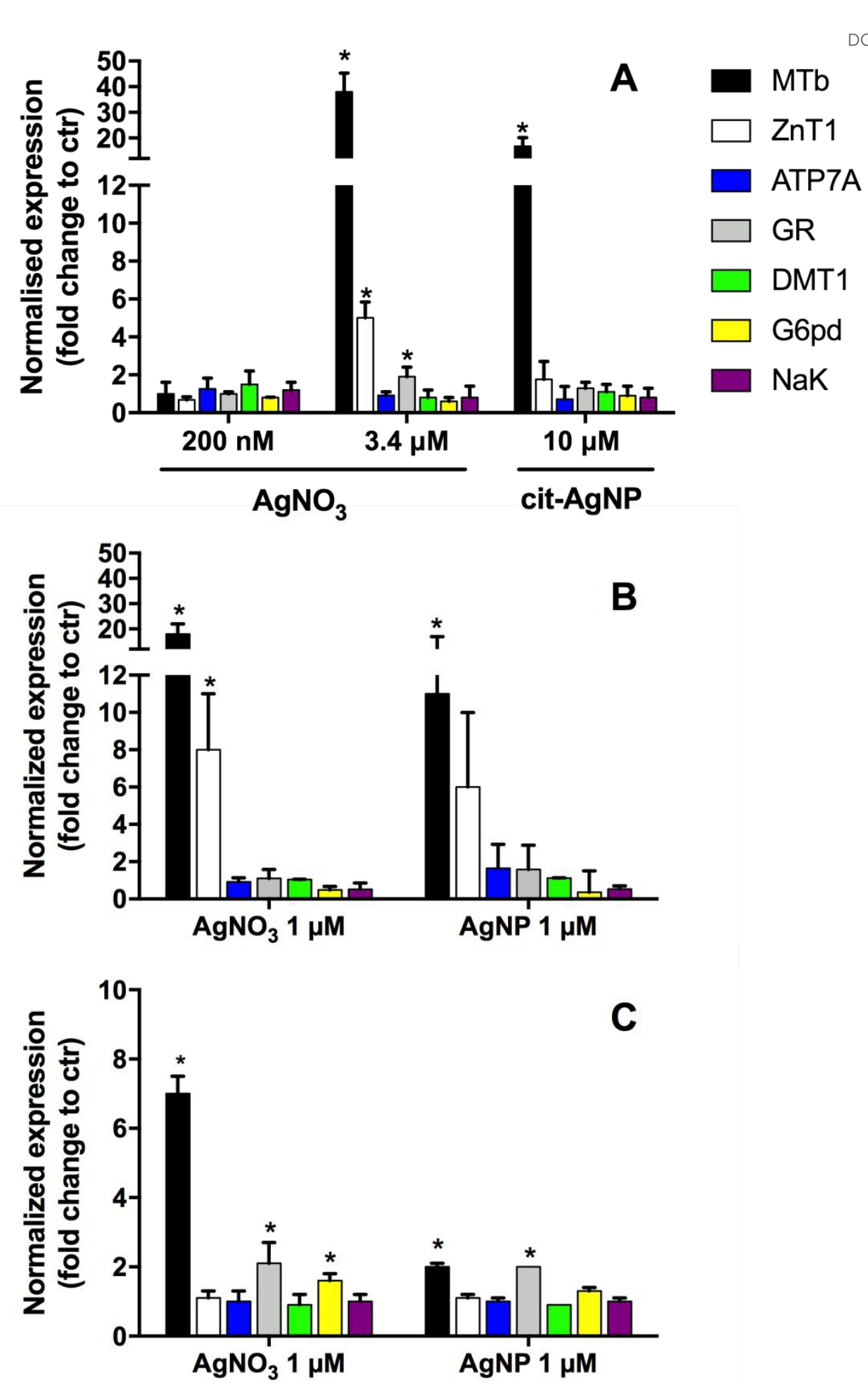

Figure 5: Normalised mRNA levels of Metallothionein b (MTb), Zinc Transporter 1 (ZnT1), Copper transporting ATPase (ATP7A or Menkes protein), Glutathione Reductase (GR), Divalent Metal Transporter 1 (DMT1), Glucose-6-Phosphate Dehydrogenase (G6pd) and Sodium-Potassium ATPase $(\mathrm{NaK})$ measured in RTgutGC cells exposed for 24 hrs to: (A) toxic doses $(\sim 20 \%$ reduction 
in viability) of $\mathrm{AgNO}_{3}$ and cit-AgNP. $200 \mathrm{nM} \mathrm{AgNO}_{3}$ is $2 \%$ of $10 \mu \mathrm{M}$ which is the measured diew Article Online $_{59 / C 9 E N 00310 J}$ dissolved fraction of silver from of cit-AgNP in L-15/ex (Yue et al., 2014); (B) non-toxic concentrations of $\mathrm{AgNO}_{3}$ and cit-AgNP in L-15/ex; (C) non-toxic concentrations of $\mathrm{AgNO}_{3}$ and citAgNP in L-15/FBS, note the y-axis scale was adjusted. All values are expressed as a ratio of the expression in those cells exposed to control media (see Figure S3). Values represent mean normalised fold change $\pm \mathrm{SD}, \mathrm{N}=3$. Statistical difference from respective control is indicated by an asterisk (1-way ANOVA, followed by Dunnett's test $\mathrm{p}<0.05)$. 


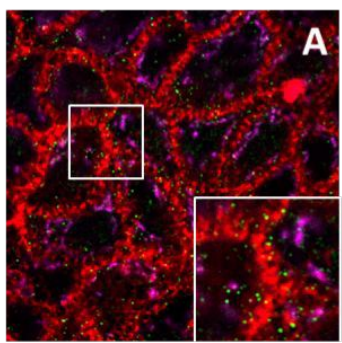

$\mathbf{F}$

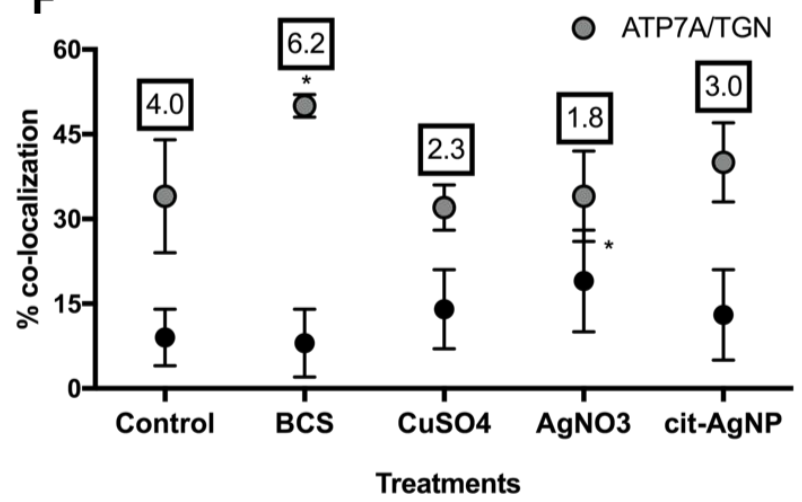

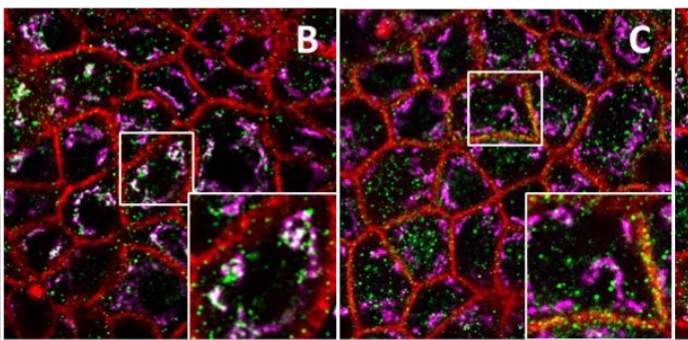
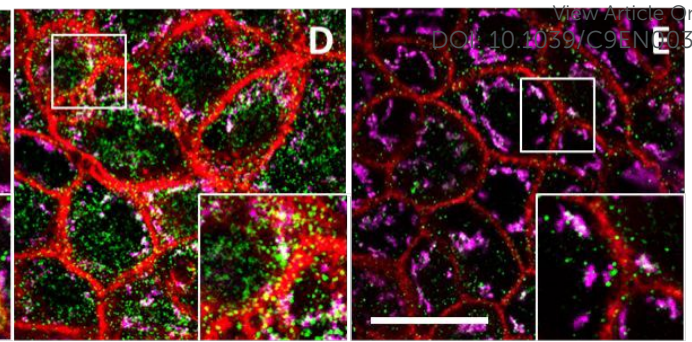

G

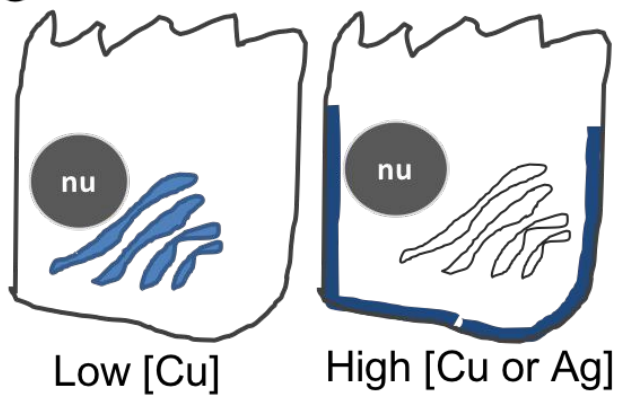

Figure 6. Metal dependent intracellular ATP7A protein localization. Caco2 cells were grown in the presence of $200 \mu \mathrm{M}$ BCS for $18 \mathrm{hrs}$ followed by the indicated treatment for $3 \mathrm{hrs}$ and processed for immunostaining. Co-localization of ATP7A (in green) with cellular markers of cell periphery (in red, f-actin) and trans golgi network (TGN, in purple, Golgin97) is shown in panels A-E. ATP7A colocalization in: A, control (DMEM +10\% FBS); B, Cu deficient (200 $\mu \mathrm{M}$ BCS); C, Cu excess (100 $\left.\mu \mathrm{M} \mathrm{CuSO}_{4}\right)$; $\mathrm{D}, \mathrm{Ag}$ excess $\left(10 \mu \mathrm{M} \mathrm{AgNO}_{3}\right) ; \mathrm{E}, \mathrm{AgNP}$ excess (80 $\mu \mathrm{M}$ cit-AgNP). Overlapping signal intensities (co-localization) were analysed and quantitated by using a laser scanning confocal microscope Leica SP5 and software 9LAS AF 2v and are shown in panel F. G, schematic representation of ATP7A co-localization under low $\mathrm{Cu}$ and high $\mathrm{Cu}$ and $\mathrm{Ag}$ intracellular concentrations. Values represent mean \pm S.D. from three independent experiments, $N=3$. Treatment effect on ATP7A co-localization with the TGN or actin (i.e. cell periphery) compared to control is indicated by an asterisk ( ${ }^{*}, \mathrm{P}<0.05,1$-way ANOVA, Dunnett's test). Boxed numbers are ratios of ATP7A co-localization with actin divided by co-localization with TGN. Insets are enlarged X2. Scale bars $=25 \mu \mathrm{m}$. 


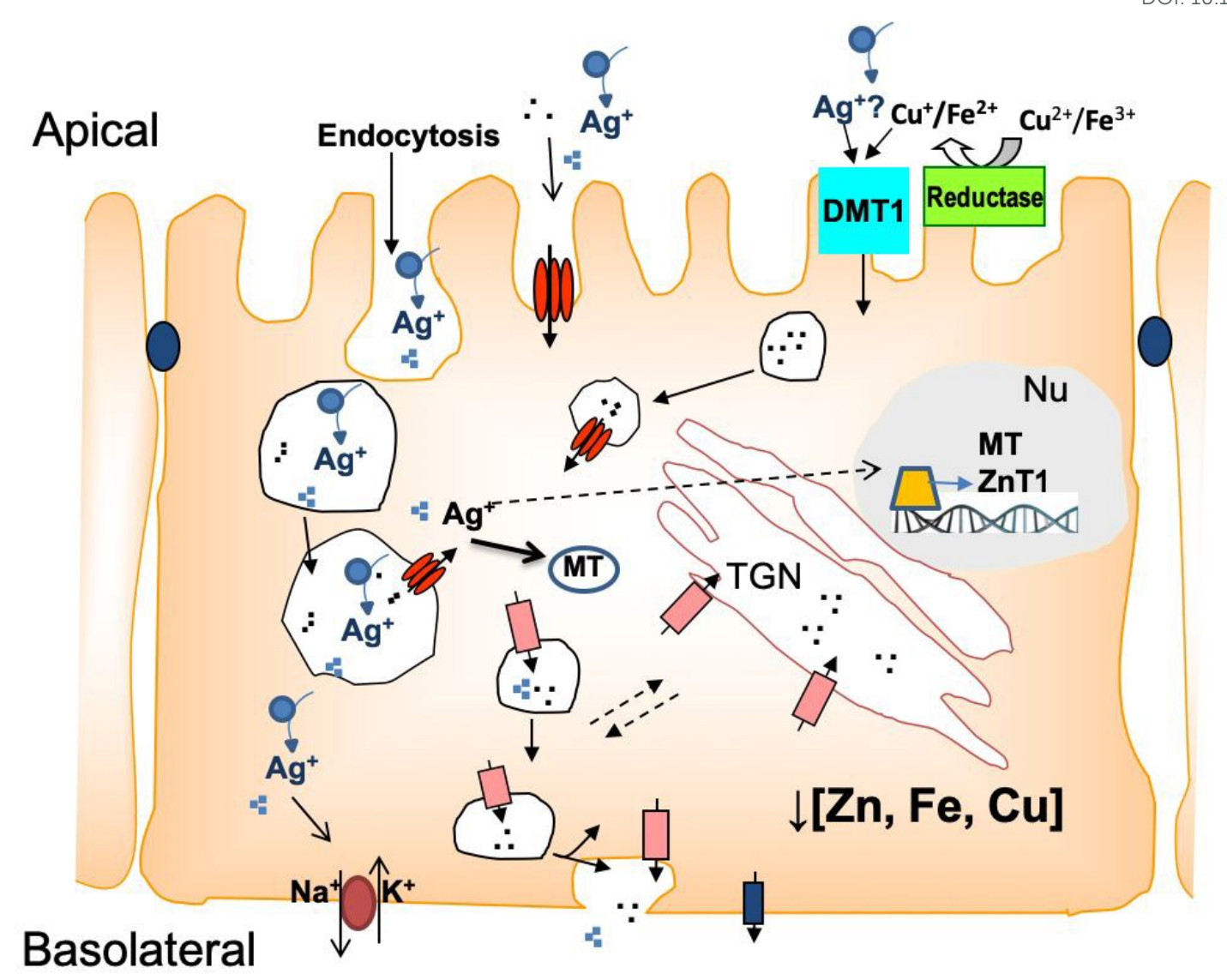

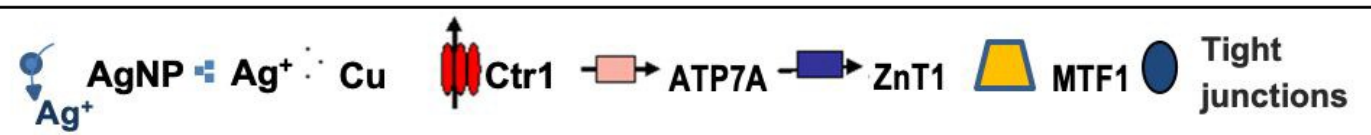

